\title{
What determines a leaf's shape?
}

\author{
Jeremy Dkhar and Ashwani Pareek
}

\begin{abstract}
The independent origin and evolution of leaves as small, simple microphylls or larger, more complex megaphylls in plants has shaped and influenced the natural composition of the environment. Significant contributions have come from megaphyllous leaves, characterized usually as flat, thin lamina entrenched with photosynthetic organelles and stomata, which serve as the basis of primary productivity. During the course of evolution, the megaphylls have attained complexity not only in size or venation patterns but also in shape. This has fascinated scientists worldwide, and research has progressed tremendously in understanding the concept of leaf shape determination. Here, we review these studies and discuss the various factors that contributed towards shaping the leaf; initiated as a small bulge on the periphery of the shoot apical meristem (SAM) followed by asymmetric outgrowth, expansion and maturation until final shape is achieved. We found that the underlying factors governing these processes are inherently genetic: PIN1 and KNOX1 are indicators of leaf initiation, HD-ZIPIII, KANADI, and YABBY specify leaf outgrowth while ANGUSTIFOLIA3 and GROWTH-REGULATING FACTOR5 control leaf expansion and maturation; besides, recent research has identified new players such as APUM23, known to specify leaf polarity. In addition to genetic control, environmental factors also play an important role during the final adjustment of leaf shape. This immense amount of information available will serve as the basis for studying and understanding innovative leaf morphologies viz. the pitchers of the carnivorous plant Nepenthes which have evolved to provide additional support to the plant survival in its nutrient-deficient habitat. In hindsight, formation of the pitcher tube in Nepenthes might involve the recruitment of similar genetic mechanisms that occur during sympetaly in Petunia.
\end{abstract}

Keywords: Leaf shape, Auxin, Polarity specification, Environmental factors, Nepenthes, Morphological novelty

\section{Introduction}

In comparison to the vibrant colors of the flower, the 'leaf' has nothing special to offer as most are greencolored attributed to the presence of chlorophyll. But their attractiveness lies in their varying shapes and sizes; from the uncommon butterfly-shaped leaf of Christia obcordata to the extensively studied ovate-shaped leaf of Arabidopsis thaliana (Figure 1A and $\mathrm{B}$ ). This variation, arising due to several factors, offers great functional significance that influences plant success [1]. In the case of leaf size, the explanation has been straightforward; it decreases with increasing altitude, decreasing rainfall, and soil nutrient content $[2,3]$. Moreover, smaller-sized leaves are better adapted to hot or dry environments [4]. However, in case of leaf shape, environmental influences viz. light, temperature, and so on have been difficult to explain [2]. Nonetheless, these factors and most importantly

\footnotetext{
* Correspondence: jeremydkhar@gmail.com

Stress Physiology and Molecular Biology Laboratory, School of Life Sciences, Jawaharlal Nehru University, New Delhi 110067, India
}

light, play special roles in the final adjustment of leaf shape [5]. But the tremendous variations observed in leaves are mostly attributed to their genetic control - the control of gene regulatory networks (GRNs) and signaling pathways that make a leaf, from a small bulge on the SAM, into a fully developed lateral outgrowth with diverse shapes. Although poorly understood, herbivory is another factor contributing to leaf shape variation [6]. Due to continued interest in this area of research, a review on the factors that determine a leaf its shape is called for. And though a similar review is available in the literature, this [5] was published almost a decade ago. Therefore, a revisit on the topic is warranted and we intend to comprehensively cover all aspects of leaf shape development that span across vascular plants with a focus on angiosperms. Our aim is to summarize these development events and the underlying mechanisms that govern them, and highlights recent advances culminating with a discussion on directions for future research. In fact, the present review lay more emphasis on the genetic control with a brief 

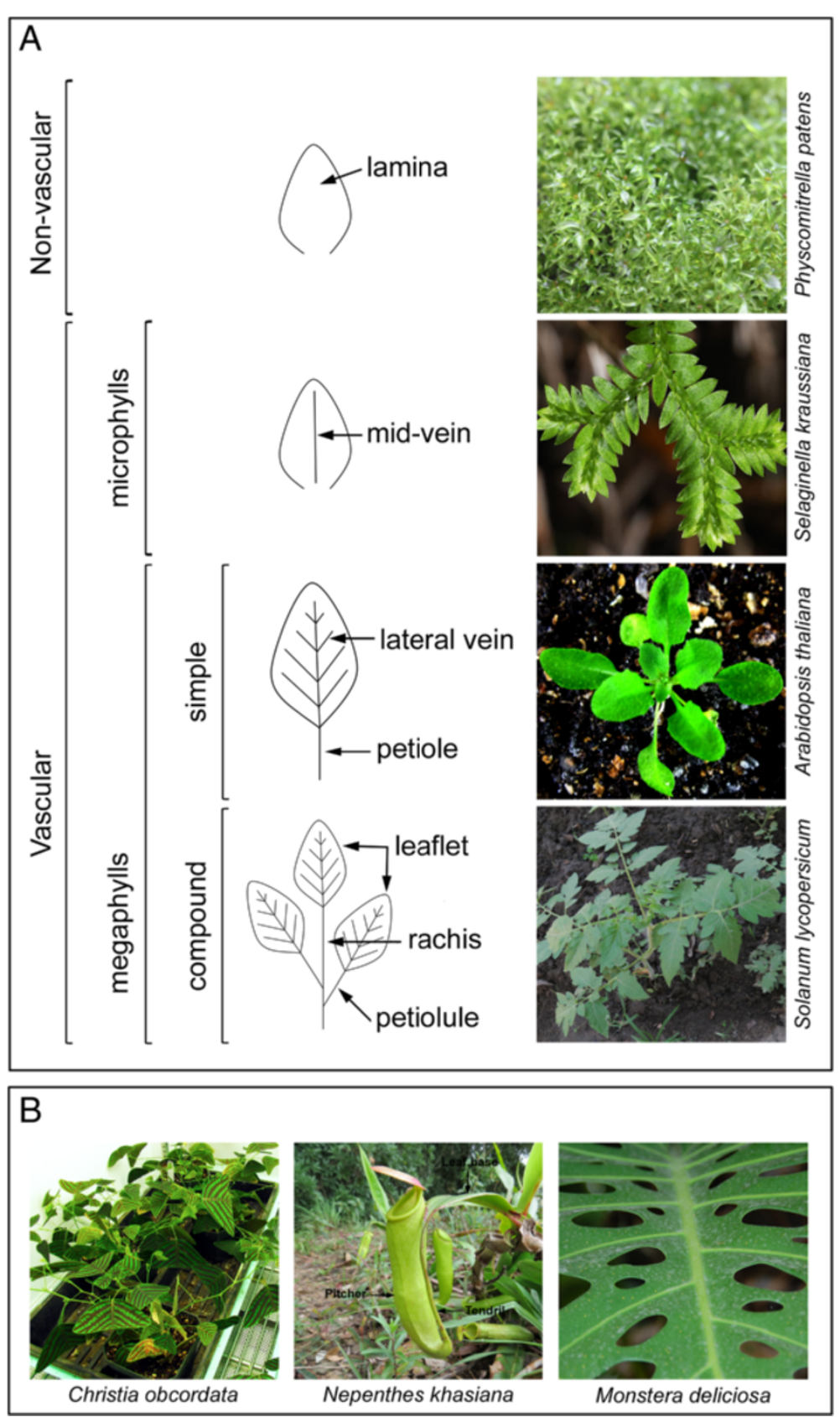

Figure 1 Diversity in leaf forms across land plants. (A) Selected representatives of the different types of leaf forms found in non-vascular and vascular model plant species viz. Physcomitrella patens (non-vascular), Selaginella kraussiana (microphyll), Arabidopsis thaliana (simple megaphyll), and Solanum lycopersicum (compound megaphyll). (B) Selected representatives of uncommon and innovative leaf morphology found in vascular non-model plant species viz. Christia obcordata (butterfly-shaped leaf), Nepenthes khasiana, and Monstera deliciosa (modified leaf). Contributors of photographs used in the figure can be found in the Acknowledgements section.

overview on the environmental components. This remarkable information garnered may open up avenues for a probable shift from model to non-model plant species showing morphological novelties, for example, pitchers of the carnivorous plant Nepenthes, modified from an otherwise unexceptional leaf (leaf base) through the formation of tendrils (Figure 1B). A note on this interesting plant genus with unusual leaf form is also presented and discussed at the concluding section.

\section{Review}

Definition, origin, and evolution of a leaf

From a layman's perspective, 'leaf' is a flattened, greencolored structure laterally attached to the stem. This 
perception may be too simple considering the remarkable diversity that leaves exhibit. As a prerequisite to their review on angiosperm leaf shape, Nicotra et al. [1] defined a leaf as a 'vascular asymmetric appendicular structure initiated at the shoot apical meristem'. This definition is applicable to all vascular plants, but does not hold true for bryophytes (mosses, liverworts, and hornworts) as they lack a well-defined system of vascular tissue [1]. In fact, the leaf-like structures of bryophytes share no homology with leaves of vascular plants. But for an organ to be considered a leaf, other basic, but delicate, morphological connections that include the dorsiventrality of the leaf and distinctive meristem distribution in relation to their symmetrical arrangement on the axis may be taken into consideration [7]. Dorsiventrality or the distinctness of the upper and lower surfaces of the leaf is evident in all land plants; prominent in vascular plants but to a lesser extent in bryophytes, observed mainly in the midrib region referred to as 'costa'. Besides this attribute of dorsiventrality, leaves become determinate, planar, and laminar structures. Considering all these views, we described a leaf as a determinate laminar structure with distinct adaxial and abaxial surfaces, formed, developed, and arranged in a particular manner on the flanks of an indeterminate SAM.

Vascularization, however, is an important anatomical characteristic that defines the two leaf types observed in vascular plants: microphylls (single vasculature) and megaphylls (complex vasculature, Figure 1A). But vasculature is not the only distinguishing feature; size (small or large) and leaf gaps (absence or presence) also differentiate the two leaf types with complexity more pronounced in megaphyllous leaves [8-11]. Examples of microphylls and megaphylls are evident in lycophytes (extant clubmosses, spikemosses, and quillworts) and euphyllophytes (comprising the extant ferns, horsetails, and seed plants), respectively. These contrasting morphological characteristics displayed correlates with an independent origin and evolution of the microphyllous and megaphyllous leaves. The two leaf types are believed to have evolved independently from simple leafless vascular plants around 480 and 360 million years ago [12]. The microphyllous leaf emerged during Late Silurian/Early Devonian era while the megaphyllous leaf evolved during the late Devonian period $[12,13]$; the latter event is linked with a $90 \%$ drop in atmospheric $\mathrm{CO}_{2}$ that corresponds with a 100-fold increase in stomatal density to avoid lethal overheating [14]. Three hypotheses have been proposed for the origin of the microphylls, but Bower's [15] 'Enation theory' is the most plausible as it is supported by an evolutionary series of related Devonian taxa, Sawdonia (and Discalis), Asteroxylon, and Drepanophycus ([16] and references therein). For megaphyll evolution, Zimmermann's telome theory has been widely accepted as the leading explanation which involves 'overtopping, planation and webbing' - three fundamental steps that transform a telome into a laminated leaf blade [17]. This theory of megaphyll evolution is similar in concept to 'evolutionary tinkering', a phenomenon that involve changes in already existing organs/forms. Furthermore, the evolution of the megaphylls occurred at least twice, once in ferns and horsetails and the other in seed plants that include the gymnosperms and angiosperms [18]. Among angiosperms, dissected or compound leaf form found in Cardamine hirsuta, pea, tomato, and so on have evolved independently from simple leaves [19].

Interestingly, the independent evolution of microphylls and megaphylls does not correspond with unique mechanisms of leaf formation; rather, common developmental mechanisms could underlie microphyll and megaphyll formation [20]. This proposition was also corroborated by a recent finding that suggests a common GRN for protonema and root hair development in Physcomitrella patens (bryophyte) and Arabidopsis thaliana, respectively [21]. Earlier, mutational and gene silencing work on four distantly related species viz. Aquilegia caerulea, Solanum lycopersicum and S. tuberosum, Cardamine hirsuta, and Pisum sativum, showed that a common underlying mechanism involving NAM/CUC3 genes promoted compound leaf development [22]. Therefore, the remarkable diversity in leaf form is a result of the common regulatory networks recruited and remodeled during the course of land plant evolution. We begin our review with the genetic basis of leaf shape determination.

\section{Genetic basis of leaf shape: genetic interactions, gene expression patterns, microRNAs, and active hormonal regulations}

Attainment of the final sizes and shapes of the plant leaf involves three major developmental events: begins with leaf initiation, followed by leaf outgrowth, and ends with leaf expansion and maturation. We highlight below the underlying genetic mechanisms that control these events. As a complement to the text, a list of all the participating genes, their functions, and mutant phenotypes is summarized in Table 1.

\section{Leaf initiation: KNOX repression and auxin accumulation}

Studies on model plant species have revolutionized our understanding on the early events of leaf initiation (Figure 2A-E). The findings showed that leaf initiation begins with the recruitment of founder cells, approximately 100 in numbers for Nicotiana tobacum [64] and Gossypium barbadense [65], at the flanks of the SAM. In eudicots, subpopulations of cells are recruited for leaf initiation while in monocots recruitment of founder cells can occur all along the circumference of the SAM $[66,67]$. The initiation of microphyll primordia in $S$. kraussiana also occurs at the periphery of the SAM [68]; 
Table 1 Genes involved in major developmental events of the leaf

\begin{tabular}{|c|c|c|c|c|c|c|}
\hline $\begin{array}{l}\text { Developmental } \\
\text { events }\end{array}$ & Genes & Description & Biological function & Mutant phenotype & Plant species & References \\
\hline \multirow[t]{5}{*}{ Leaf initiation } & PIN-FORMED1 (PIN1) & Transmembrane protein & Auxin efflux & $\begin{array}{l}\text { Develop naked, pin-shaped inflorescences; } \\
\text { leaves become fused; phyllotaxy disrupted }\end{array}$ & Arabidopsis thaliana & {$[23-25]$} \\
\hline & $\begin{array}{l}\text { Class-1 KNOTTED-like } \\
\text { homeobox (KNOX1) }\end{array}$ & Homeodomain protein & Maintain stem cell identity & $\begin{array}{l}\text { Loss-of-function mutants failed to develop } \\
\text { SAM; gain-of-function mutants showed ec- } \\
\text { topic SAMs on leaves }\end{array}$ & $\begin{array}{l}\text { Arabidopsis thaliana; } \\
\text { Zea mays }\end{array}$ & {$[26,27]$} \\
\hline & WUSCHEL (WUS) & Homeodomain protein & $\begin{array}{l}\text { Maintain shoot and floral } \\
\text { central meristem identity }\end{array}$ & $\begin{array}{l}\text { Delayed growth; disorganized rosette leaves; } \\
\text { inflorescence meristem defective }\end{array}$ & Arabidopsis thaliana & [28] \\
\hline & CLAVATA (CLV) & $\begin{array}{l}\text { CLV1 (receptor kinase); CLV2 } \\
\text { (transmembrane protein); CLV3 } \\
\text { (extracellular protein) }\end{array}$ & Maintain stem cell size & $\begin{array}{l}\text { Enlarged shoot and floral meristems; stem } \\
\text { overgrowth; additional floral organs }\end{array}$ & Arabidopsis thaliana & {$[29,30]$} \\
\hline & $\begin{array}{l}\text { ASYMMETRIC LEAVES1/ } \\
\text { ROUGH SHEATH2/ } \\
\text { PHANTASTICA (ARP) }\end{array}$ & MYB domain protein & Stem cell differentiation & $\begin{array}{l}\text { Stunted growth; polarity defects; unlike as } 1 \\
\text { and rs2, phan leaves are radialized }\end{array}$ & $\begin{array}{l}\text { Arabidopsis thaliana; } \\
\text { Zea mays; Antirrhinum } \\
\text { majus }\end{array}$ & {$[31-34]$} \\
\hline \multirow[t]{2}{*}{$\begin{array}{l}\text { Leaf outgrowth: } \\
\text { proximodistal } \\
\text { patterning }\end{array}$} & KNOTTED1 (KN1) & Homeodomain protein & Maintain stem cell identity & $\begin{array}{l}\text { Gain-of-function mutants displayed flaps of } \\
\text { sheath tissue at leaf blade margin; leaf } \\
\text { bifurcated }\end{array}$ & Zea mays & {$[35]$} \\
\hline & $\begin{array}{l}\text { LIGULELESS NARROW- } \\
\text { REFERENCE (LGN-R) }\end{array}$ & Serine/threonine kinase & $\begin{array}{l}\text { Establishment of blade/sheath } \\
\text { boundary }\end{array}$ & $\begin{array}{l}\text { Heterozygotes displayed narrower and } \\
\text { shorter leaves; homozygotes failed } \\
\text { reproductive development }\end{array}$ & Zea mays & {$[36]$} \\
\hline \multirow{8}{*}{$\begin{array}{l}\text { Leaf outgrowth: } \\
\text { dorsoventral } \\
\text { patterning }\end{array}$} & PHANTASTICA (PHAN) & MYB domain protein & Stem cell differentiation & $\begin{array}{l}\text { Loss-of-function phan mutants develop } \\
\text { needle-like leaves lacking dorsoventrality }\end{array}$ & Antirrhinum majus & [37] \\
\hline & $\begin{array}{l}\text { ASYMMETRIC LEAVES2 } \\
\text { (AS2) }\end{array}$ & LOB domain protein & $\begin{array}{l}\text { Leaf venation pattern and } \\
\text { lamina development }\end{array}$ & $\begin{array}{l}\text { Develop narrow and curly leaves with } \\
\text { alteration in adaxial/abaxial polarity }\end{array}$ & Arabidopsis thaliana & {$[38]$} \\
\hline & $\begin{array}{l}\text { Class III } \\
\text { HOMEODOMAIN- } \\
\text { LEUCINE ZIPPER } \\
\text { (HD-ZIPIII) }\end{array}$ & $\begin{array}{l}\text { Homeodomain and leucine zipper } \\
\text { domain protein }\end{array}$ & Leaf polarity, meristem function & $\begin{array}{l}\text { Lateral organs radialized with adaxial cell } \\
\text { fate transformation; modification in vascular } \\
\text { patterning }\end{array}$ & Arabidopsis thaliana & {$[39,40]$} \\
\hline & KANADI (KAN) & GARP domain protein & Leaf polarity specification & $\begin{array}{l}\text { Develop narrow adaxialized lateral organs; } \\
\text { ectopic outgrowths on leaves; gain-of- } \\
\text { function mutants displayed abaxialized cell } \\
\text { types; blade expansion inhibited }\end{array}$ & Arabidopsis thaliana & {$[41,42]$} \\
\hline & APUM23 & PUF RNA-binding protein & Leaf polarity specification & $\begin{array}{l}\text { Radialized leaves; disorganized vascular } \\
\text { pattern }\end{array}$ & Arabidopsis thaliana & [43] \\
\hline & $\begin{array}{l}\text { AUXIN RESPONSE } \\
\text { FACTOR (ARF) }\end{array}$ & $\begin{array}{l}\text { Protein with N-terminal DNA binding } \\
\text { domain, activator/repressor domain, } \\
\text { C-terminal dimerization domain }\end{array}$ & Leaf polarity specification & $\begin{array}{l}\text { Narrow leaves with ectopic blade } \\
\text { outgrowths }\end{array}$ & Arabidopsis thaliana & [44] \\
\hline & miR165 & 21-nucleotide non-coding RNAs & $\begin{array}{l}\text { Leaf polarity specification, } \\
\text { meristem function, vascular } \\
\text { development }\end{array}$ & $\begin{array}{l}\text { Loss of SAM; altered organ polarity; } \\
\text { defective vascular development }\end{array}$ & Arabidopsis thaliana & {$[45]$} \\
\hline & $\operatorname{miR} 166$ & 21-nucleotide non-coding RNAs & $\begin{array}{l}\text { Leaf polarity specification, } \\
\text { meristem function, vascular } \\
\text { development }\end{array}$ & $\begin{array}{l}\text { Enlarged SAM; enhanced vascular } \\
\text { development }\end{array}$ & Arabidopsis thaliana & [46] \\
\hline
\end{tabular}

\section{proximodistal \\ patterning}

Leaf outgrowth: PHANTASTICA (PHAN) dorsoventral

$$
\text { (AS2) }
$$

class III

$(H D-Z I P I I I)$

KANADI (KAN)

AUXIN RESPONSE

miR165

miR166 
Table 1 Genes involved in major developmental events of the leaf (Continued)

\begin{tabular}{|c|c|c|c|c|c|c|}
\hline & $\begin{array}{l}\text { RNA-DEPENDENT RNA } \\
\text { POLYMERASEG (RDR6)/ } \\
\text { DICER-LIKE4 (DCL4) }\end{array}$ & $\begin{array}{l}\text { RNA-dependent RNA polymerase/ } \\
\text { RNase-III enzyme }\end{array}$ & Leaf polarity specification & $\begin{array}{l}\text { Accelerated juvenile-to-adult phase transi- } \\
\text { tion; early development of adult lateral or- } \\
\text { gans; lack ta-siRNAs }\end{array}$ & Arabidopsis thaliana & {$[47-49]$} \\
\hline \multirow{5}{*}{$\begin{array}{l}\text { Leaf outgrowth: } \\
\text { mediolateral } \\
\text { patterning }\end{array}$} & $Y A B B Y(Y A B)$ & $\begin{array}{l}\text { Protein with zinc-finger and helix- } \\
\text { loop-helix domains }\end{array}$ & $\begin{array}{l}\text { Leaf polarity specification, } \\
\text { lamina expansion }\end{array}$ & $\begin{array}{l}\text { Minuscule and bushy plants with loss of } \\
\text { lamina expansion and polarity defects }\end{array}$ & Arabidopsis thaliana & {$[50,51]$} \\
\hline & Narrow sheath (ns) & Homeodomain protein & $\begin{array}{l}\text { Leaf founder cell recruitment, } \\
\text { leaf expansion }\end{array}$ & $\begin{array}{l}\text { Develop extremely narrow leaves; short } \\
\text { internode }\end{array}$ & Zea mays & {$[52,53]$} \\
\hline & PRESSED FLOWER (PRS) & Homeodomain protein & Marginal cell proliferation & Smaller sepals; defective marginal regions & Arabidopsis thaliana & [54] \\
\hline & MAEWEST (MAW) & Homeodomain protein & $\begin{array}{l}\text { Organ fusion and lateral } \\
\text { expansion }\end{array}$ & $\begin{array}{l}\text { Severe leaf blade reduction, thickened leaf } \\
\text { margins; petal expansion reduced; defective } \\
\text { carpel fusion }\end{array}$ & Petunia $\times$ hybrida & [55] \\
\hline & YUCCA (YUC) & Flavin monooxygenase & $\begin{array}{l}\text { Leaf and vascular development, } \\
\text { floral patterning }\end{array}$ & $\begin{array}{l}\text { Stunted growth with curved leaves; smaller } \\
\text { inflorescence meristem; defective floral and } \\
\text { leaf vasculature }\end{array}$ & Arabidopsis thaliana & {$[56,57]$} \\
\hline \multirow[t]{3}{*}{$\begin{array}{l}\text { Leaf expansion } \\
\text { and maturation }\end{array}$} & $\begin{array}{l}\text { ANGUSTIFOLIA (AN3)/ } \\
\text { GRF-INTERACTING } \\
\text { FACTORI(GIF1) }\end{array}$ & Transcription coactivator & Cell expansion & $\begin{array}{l}\text { Reduced leaf width and length; petal width } \\
\text { reduction; more leaf number }\end{array}$ & Arabidopsis thaliana & {$[58,59]$} \\
\hline & $\begin{array}{l}\text { GROWTH-REGULATING } \\
\text { FACTOR5 (GRF5) }\end{array}$ & $\begin{array}{l}\text { Transcription activators containing } \mathrm{N} \text { - } \\
\text { terminal QLQ or WRC domain }\end{array}$ & Cell proliferation & $\begin{array}{l}\text { Loss-of-function mutants displayed narrow } \\
\text { leaves and petals; gain-of-function mutants } \\
\text { develop }\end{array}$ & Arabidopsis thaliana & {$[58,59]$} \\
\hline & CINCINNATA (CIN) & TCP domain protein & Cell proliferation & Develop large crinkly leaves & Antirrhinum majus & [60] \\
\hline \multirow[t]{4}{*}{$\begin{array}{l}\text { Leaf margin } \\
\text { alterations }\end{array}$} & $\operatorname{miR} 164 A$ & Non-coding miRNA & Leaf margin development & $\begin{array}{l}\text { Enhanced leaf margin serration in loss-of- } \\
\text { function mutants; gain-of-function mutants } \\
\text { develop leaves with smooth margins }\end{array}$ & Arabidopsis thaliana & [61] \\
\hline & $\begin{array}{l}\text { CUP-SHAPED } \\
\text { COTYLEDON2 (CUC2) }\end{array}$ & $\begin{array}{l}\text { Protein containing the NAC DNA- } \\
\text { binding domain }\end{array}$ & $\begin{array}{l}\text { Shoot meristem formation; } \\
\text { organ boundary specification; } \\
\text { leaf margin development }\end{array}$ & Produced leaves with smooth margins & Arabidopsis thaliana & [61] \\
\hline & PIN-FORMED1 (PIN1) & Transmembrane protein & Auxin efflux & $\begin{array}{l}\text { Loss-of-function mutants develop smooth } \\
\text { leaf margins }\end{array}$ & Arabidopsis thaliana & [62] \\
\hline & $\begin{array}{l}\text { DEVELOPMENT- } \\
\text { RELATED PCG TARGET } \\
\text { IN THE APEX (DPA) }\end{array}$ & RAV transcription repressor & $\begin{array}{l}\text { Organ initiation and } \\
\text { development; leaf margin } \\
\text { development }\end{array}$ & $\begin{array}{l}\text { Loss-of-function mutants showed increased } \\
\text { leaf margin serrations and enlarged petals; } \\
\text { gain-of-function mutants possessed smooth } \\
\text { margins }\end{array}$ & Arabidopsis thaliana & [63] \\
\hline
\end{tabular}




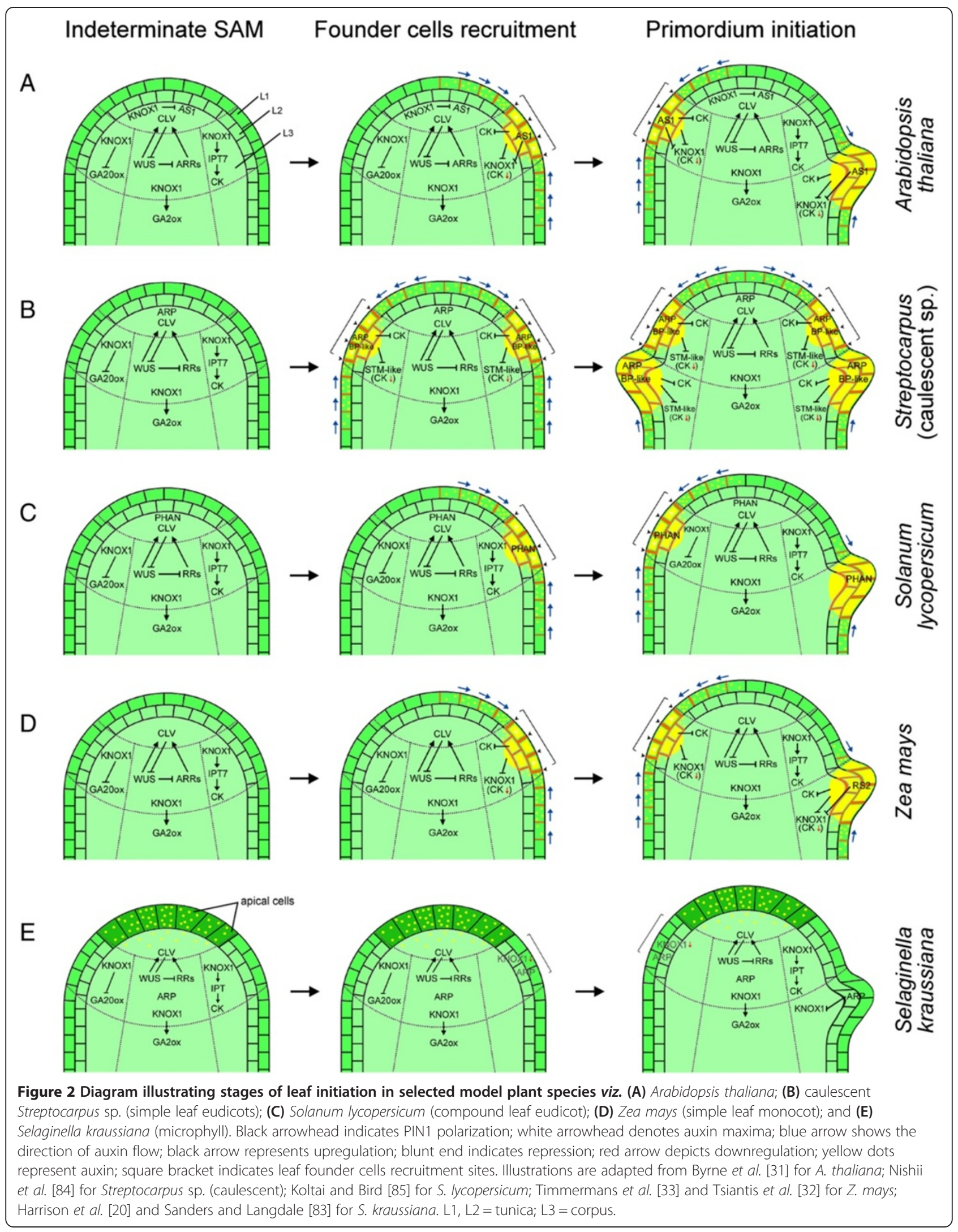


however, fewer founder cells (12 to 16) are recruited [69]. But what drives leaf initiation at the periphery of the SAM is yet to be fully ascertained, despite the fact that it corresponds with the concurrent repression of class-1 KNOTTED-like homeobox (KNOX) genes [26,70,71] and local auxin accumulation mediated predominantly by the auxin efflux carrier PIN-FORMED1 (PIN1) [23-25] (Figure 2AD). In Arabidopsis thaliana (henceforth referred to as Arabidopsis), the transmembrane protein PIN1 is strongly expressed in epidermal cells of the SAM and its apical polarization results in the creation of an auxin gradient with maxima directed towards sites of incipient leaf primordia [23-25,72-75] (Figure 2A). This in turn acts as an auxin sink that is transported basally to promote formation of provascular tissues, creating a field of auxin depletion around the incipient and bulging primordia [76,77]. The change in auxin transport corresponds with strong PIN1 expression in the central vasculature of developing leaf primordia [25]. In other plant species, for example, maize, the expression pattern of PIN1 is identical to Arabidopsis, although ZmPIN1 localization is also observed in the corpus (L3) of SAM [78]. In C. hirsuta, PIN1 facilitate leaflet formation through high auxin activity in the margin of the leaf rachis [79]. These observations suggest that the distribution of auxin maxima, either in the meristem flank or leaf margin, determine where leaf/leaflet primordia originate. Besides auxin concentration and flow, the control of PIN1 localization and expression has also been attributed to mechanical stresses, occurring due to tight interactions between growing cells [80]. Recently, a membrane-bound protein BIG is thought to affect PIN1 protein level by regulating its transcription [81]. However, the exclusive role of PIN1 in leaf initiation is still debatable owing to the normal development of pin1 mutant leaves during early vegetative growth in Arabidopsis [23,24]. In an attempt to understand this surprising development, Guenot et al. [82] investigated other plasma-membrane localized PIN proteins (PIN2, PIN3, PIN4, and PIN7) to uncover if they could compensate for the loss of PIN1 during rosette leaves formation in Arabidopsis. Surprisingly, none of these proteins were expressed in the SAM, suggesting that other auxin transporters, auxin synthesis, and auxin-independent mechanisms of leaf initiation in Arabidopsis exist [82]. Recent evidences from S. kraussiana suggest that the underlying molecular mechanisms for polar auxin transport (PAT) are likely to be conserved across all vascular plants [83]; however, auxin does not promote leaf initiation in S. kraussiana [83]. This finding implies that an auxin-independent mechanism for leaf initiation in S. kraussiana exists that remained conserved throughout vascular plants evolution and recruited during early vegetative growth in Arabidopsis.

Another critical event occurring at the SAM prior to the initiation of leaf primordia is the downregulation of
KNOX1 genes (Figure 2A-E). KNOX1 proteins function in the maintenance of stem cell identity - mutational studies have shown that Arabidopsis and maize plants with loss-of-function mutations in KNOX1 genes failed to maintain SAM [26,27] - and repression of these genes changes the indeterminacy state of stem cells to determinate ones. This organogenic switch is controlled by the relative amount of two phytohormones: cytokinin (CK) and gibberellin (GA), responsible for cell division and cell elongation, respectively [86]. High CK to low GA ratio promotes indeterminacy of SAM while low CK to high GA ratio facilitates determinacy. In Arabidopsis, the high CK to low GA ratio is achieved through KNOX1 proteins via upregulation of cytokinin biosynthesis genes isopentenyl transferase 7 (IPT7) $[87,88]$ and repression of GA20-oxidase gene [89]. In maize, GA level is reduced by a direct upregulation of the GA catabolism gene ga2ox1 [90] (Figure 2D). Similarly, GA2ox2 mRNA level in Arabidopsis leaves increased in response to higher levels of cytokinin and KNOX1 expression [87]. Another KNOX-independent genetic pathway involving WUSCHEL (WUS) and CLAVATA (CLV), which acts in the central zone of meristem, control stem cell fate by direct regulation of cytokinin-inducible response regulators [28-30,91] (Figure 2A-E).

The low CK to high GA ratio is attained through different pathways of KNOX1 downregulation. One of the pathways is mediated by auxin through polar transport at sites of incipient leaf primordia thereby repressing KNOX1 [92] and CK signaling [93,94] (Figure 2A-D). Another pathway involves MYB transcription factors encoded by the ARP genes. ASYMMETRIC LEAVES1 (AS1) of Arabidopsis [31], rough sheath2 (rs2) of maize [32,33], and PHANTASTICA (PHAN) of Antirrhinum [34] (hence the name ARP) are explicitly expressed in lateral organs founder cells and negatively regulate respective KNOX1 gene expression (Figure 2A, D). This requires the interaction of AS1 and RS2 with HIRA, a chromatin-remodeling factor that could alter local chromatin organization at the KNOX1 loci [95]. It becomes evident that the ARP/KNOX regulatory module is mutually exclusive, common in most simple leaved species with the exception of Streptocarpus, wherein KNOX1 and ARP are co-expressed in leaf primordia $[84,96]$ (Figure 2B). Co-expression of ARP/KNOX module is also observed in most compound leaved species and their expression pattern varies from one species to another [85,97] (Figure 2C). Interestingly, the ARP/KNOX module in Selaginella is either mutually exclusive (leaves and stem) or overlapping (meristem) [20] (Figure 2E). This co-expression might facilitate shoot bifurcation in Selaginella [20], delays maturation of the compound leaf to allow leaflet formation [98], and promotes macrocotyledon growth and meristem development in Streptocarpus [84]. 
Recent evidence has suggested another mode of KNOX repression involving an epigenetic interaction between Arabidopsis AS1-ASYMMETRIC LEAVES 2 (AS2) complex and POLYCOMB REPRESSIVE COMPLEX (PRC) 2 to stably silence the stem cell regulators [99]. The AS2 gene encodes an AS2/LOB domain-containing protein comprising a cysteine repeat motif and a leucine-zipperlike sequence in its amino-terminal half [100]. Hence, the multiple levels of regulation may explain the crucial role that KNOX1 genes play in leaf development because misexpressions have resulted in adverse phenotypes [101], thereby reducing plant success.

\section{Leaf outgrowth: change in division pattern along three axes}

At the phenotypic level, leaf initiation is recognized by the appearance of a bulge at sites on the periphery of the SAM where KNOX1 repression and auxin maxima occur (Figure 3A). Immediately after primordial initiation, determinate cells are induced to change division pattern along three axes: proximal/distal, adaxial/abaxial, and medial/lateral (Figure 3B). Each axis is discussed below.

\section{Proximal/distal patterning: so much yet so little known}

The proximal/distal axis is established with the initiation of leaf primordia $[35,102]$. Its determination was thought to be independent of dorsalizing function, as needle-like leaves of phan mutants having no lateral outgrowth retained their proximodistal axis [37]. However, evidences from mutants of KANADI and YABBY gene family (regulators of adaxial/abaxial polarity) displaying shorter leaf length have suggested otherwise [103]. Ramirez et al. [35] showed that gain-of-function knotted1 (kn1-DL) mutants produced flaps of sheath-like tissue along the maize leaf margins caused by the misexpression of $k n 1$ in these regions. This finding highlights the probable role of KN1 in proximal/distal polarity, creating a juxtaposition of proximal ( $k n 1$ expressing) and distal cells (blade) in $k n 1$ DL mutants [35]. Recently, Moon et al. [36] identified a new mutation in maize, Liguleless narrow-Reference (Lgn$R$ ), mapped to a grass-specific kinase. Homozygous L $g n-R$ mutants displayed reduced leaf width and length, are significantly shorter in height and lack reproductive organs as compared to wild type, suggestive of its role in proximal/distal patterning [36]. Although no definite genetic marker(s) has been found associated with proximodistal axis, these studies have paved the way towards identifying genes specifying proximal/distal axis in leaf development.

\section{Adaxial/abaxial patterning: class III HD-ZIPs, microRNAs, $K A N A D I$, and auxin interacting factors}

Experiments to establish the mechanism of adaxial/abaxial polarity in leaf development started around 60 years ago through surgical incisions separating incipient primordia from the apical meristem [104,105]. Resulting potato leaves were mostly centric and abaxialized caused either by cessation of apical growth or elimination of its effect [104]. Laser-based techniques to ablate tomato leaf primordia yielded similar results, producing plants (65\%) with partial or complete loss of lateral leaflets and removal of

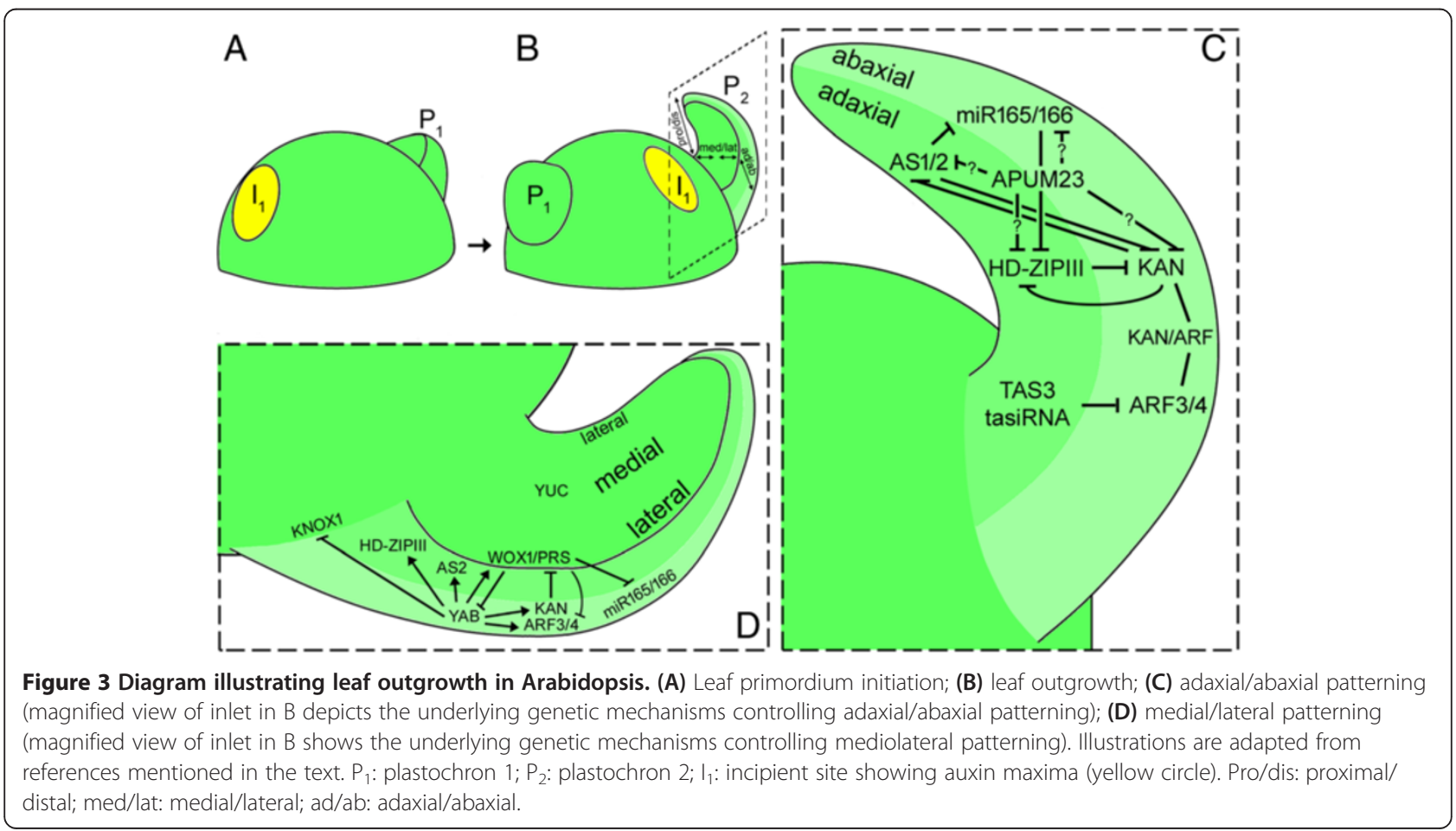


the L1 layer of the SAM eliminated dorsoventral polarity [106]. These results suggest that a signal emanating from the SAM is required for normal adaxial/abaxial patterning and draw attention to the L1 layer playing a role in the establishment of the adaxial domain of leaf primordia. Similar phenotypes were observed in loss-of-function phan mutants of Antirrhinum majus, identifying PHAN as a determinant for maintaining the adaxial identity [37]. They demonstrated a relationship between adaxial/abaxial polarity and lamina outgrowth, and hypothesized that the juxtaposition of adaxial and abaxial identity promotes lamina outgrowth. Although PHAN and its orthologues (referred as ARP gene family) are uniformly expressed in young leaf primordia of respective species, their roles in adaxial specification are not strictly conserved. Abaxialization due to knockdown of PHAN orthologues is observed in certain lineages viz. LePHAN in tomato [107], but not in maize (RS2) [33] or Arabidopsis (AS1) [31]. Surprisingly, overexpression of AS2 in Arabidopsis resulted in plants with narrower curly leaves displaying dramatic alteration in the identity of both adaxial and abaxial epidermal cells and the abaxial side showed mostly adaxial features [38]. Furthermore, mutants of the indeterminate gametophyte1 (ig1) gene in maize, sharing sequence similarity with $A S 2$ of Arabidopsis, produced leaves with defective adaxial/abaxial specification [108]. These studies highlight the role of AS2 in maintaining adaxial identity.

The adaxial/abaxial axis is also established at leaf initiation, and represents an important axis that require proper establishment for proper lamina outgrowth. In Arabidopsis, PHABULOSA (PHB), PHAVOLUTA (PHV), and REVOLUTA (REV), members of the class III HOMEODOMAIN-LEUCINE ZIPPER (HD-ZIPIII) gene family, play vital roles in adaxial/abaxial polarity specification, and are expressed in the adaxial domain of developing leaf primordia to specify adaxial cell fate [39,109] (Figure 3C). Arabidopsis plants with dominant mutations in $p h b$ and $p h v$ developed rod-shaped or trumpet-shaped leaves with adaxial characters around their circumference [39] while gain-of-function alleles of rev resulted in adaxialized lateral organs mediated by microRNAs - miR165 and miR166 [40]. In fact, expression of HD-ZIPIII genes in the abaxial domain are repressed by miR165/166 [45,46]. Ectopic/constitutive overexpression of MiR165 and miR166 produced contrasting phenotypes with comparable reduction in transcript levels of $H D-Z I P$ III genes [45,46]. In rice, four out of five class III $H D$-ZIP genes, OSHB1 to OSHB4, control adaxial/abaxial patterning and are similar in gene structure and expression patterns to Arabidopsis $H D$-ZIPIII genes. Mutations in the miR166-binding sites of these OSHB genes, particularly OSHB1 and OSHB3, resulted in leaf polarity defects with varying degree of severity [110]. These studies suggested a conserved functional role of HD-ZIPIII genes in Arabidopsis, rice, maize (rolled leaf1 (rld1) and leafbladeless1 (lbl1) [111]) and most likely across angiosperms [112].

Abaxial identity in leaves requires the function of KANADI gene family, encoding nuclear-localized GARPdomain transcription factors, which are expressed in the abaxial domain of leaf primordia (Figure 3C). In Arabidopsis - of which four KAN (1-4) genes are present - lossof-function kan1 mutants showed apparent disruption in adaxial/abaxial cell gradient as compared to wild type whereas transgenic seedlings, with KAN1 fused to a constitutive CAMV 35S promoter, developed elongated and pointed cotyledons with no subsequent leaves production [41]. Similar results were obtained when KAN1, KAN2, and KAN3 genes were ectopically expressed using the $35 \mathrm{~S}$ promoter, but severe alteration in leaf polarity occurred in kan1 kan2 double mutants [42]. kan1 kan2 plants develop narrow cotyledons and leaves with ectopic outgrowths on their abaxial side, and displayed adaxialized lateral organs, particularly petals and carpels [42]. Eshed et al. [103] extended their study on the triple mutants of $K A N(1-3)$ and observed that mutant leaves, although radialized initially, maintained some level of polarity during development. Interestingly, the expression pattern of the $P H B$ gene in the kan1 kan 2 kan 3 background was altered, expressing throughout the developing leaf with a maximum level at the adaxial domain indicating that $K A N$ genes antagonistically regulate $H D$-ZIPIII genes [103] (Figure 3C). A recent study corroborated this finding, indicating that KAN and HD-ZIPIII have opposing effects on genes that are involved in auxin biosynthesis and transport, for example, TAA1, NPH3-like genes, and so on, while PIN4 is repressed by KAN [113]. This finding highlights the importance of the adaxial/abaxial pathway in patterning auxin synthesis, transport, and signaling. Since this antagonistic effect arises during cotyledon formation; it is assumed that similar responses could occur during leaf development [113]. APUM23, encoding PUF RNA-binding protein family, has been identified as a new player of leaf polarity specification in Arabidopsis [43] (Figure 3C). Mutation in APUM23 increases the severity of kan1 kan 2 mutant leaf phenotypes, displaying enhanced reduction in blade expansion. Moreover, RT-PCR revealed overexpression of the two KAN genes as well as $P H B, R E V, A S 1$, and $A S 2$ in the triple mutant as compared to wild type [43]. These evidences suggest that APUM23 act to indirectly regulate the expression of major adaxial/abaxial leaf polarity genes [43].

The other gene family known to specify abaxial cell fate is the AUXIN RESPONSE FACTOR (ARF) family, which function by binding to auxin response elements on promoters of auxin response genes and transduce auxin signal during plant growth and development. Evidence that points to their role in adaxial/abaxial polarity emerged from mutational studies and expression pattern 
of ETT (also known as ARF3) and ARF4 in Arabidopsis [44]. Severe polarity defects were observed in ett-1 arf4-1 and ett-1 arf4-2 double mutant plants resulting in abaxialized leaves similar to kan1 kan2 mutants [44], suggesting a key relationship between $K A N$ and $A R F$. Evidently, a direct interaction between ETT and KANADI (KAN1 and KAN4) was reported, and their overlapping expression pattern suggests common regulatory function in polarity establishment and organogenesis [114] (Figure 3C). In turn, both ETT and ARF4 were earlier shown as targets of TAS3 derived trans-acting siRNAs (ta-siRNAs) and displayed marked upregulated expression in siRNA- and miRNA-defective mutants [115] (Figure 3C). In Arabidopsis, loss-of-function mutations in key TAS3 tasiRNA biogenesis genes, encoding RNA-DEPENDENT RNA POLYMERASE6 (RDR6) and DICER-LIKE4 (DCL4), resulted in plants with accelerated juvenile-to-adult phase transition and early development of adult lateral organs characteristics as compared to wild type $[47,48]$. But when a ta-siRNA-insensitive ETT, generated by introducing silent mutations into target sites, or ETT were expressed in a $r d r 6-15$ mutant background, defects in leaf morphology was observed [49]. The transgenic plants displayed narrow, highly twisted, curly and irregularly shaped leaves or in severe cases, the appearance of deeply lobed leaves with ectopic radial leaf primordia on the abaxial surface [49]. These results specify TAS3 ta-siRNAs as negative regulators of abaxial cell fate through the regulation of ETT and ARF4 [49], thereby identifying small RNAs as key players of adaxial/abaxial polarity specification.

\section{Medial/lateral patterning: role of $Y A B B Y$ and WOX gene family}

Proper establishment and juxtaposition of the adaxial and abaxial domain is required for lamina outgrowth, which initiates at the adaxial/abaxial boundary and develop along an axis referred to as the medial/lateral axis (Figure 3B and D). As lamina outgrowth involves cell division followed by cell elongation and differentiation, the adaxial/abaxial boundary formed in early developing leaf primordia represents another leaf meristematic zone called plate meristem or blastozone $[116,117]$. The morphogenetic capacity of the blastozone ensures formation of the lamina and other structures such as lobes and leaflets; improper or loss of lamina outgrowth is a consequence of defective leaf adaxial/abaxial polarity as evident from mutant analyses mentioned above. Although initially thought to be a major component of abaxial cell fate specification because of its expression pattern and gain-offunction alleles [118], the $Y A B B Y$ gene family is a primary player of medial/lateral specification (Figure 3D). In Arabidopsis, six members of the $Y A B B Y$ gene family have been identified [119] and are known to encode transcription factors with a zinc-finger and a helix-loop-helix motif.
These include FILAMENTOUS FLOWER (FIL), YABBY2 (YAB2), YAB3, and YAB5, which are expressed in leaf primordia, and CRABS CLAW (CRC) and INNER NO OUTER (INO) that are localized to the floral organs. Double mutants of fil and yab3 genes displayed partially radialized leaves but maintained adaxial/abaxial polarity to a larger extent as both adaxial and abaxial surface cell types can be easily distinguished [50]. Sarojam et al. [51] extended their investigation to all four vegetative $Y A B B Y$ genes and found that the severity of polarity defects and loss of lamina outgrowth were more pronounced in triple mutant fil-8 yab3-2 yab5-1 (yab135) and quadruple mutant fil-8 yab2-1 yab3-2 yab5-1 (yab1235) plants as compared to the double mutants, though initial polarity establishment remained intact. These results indicated that the lack of lamina outgrowth and polarity maintenance is associated with the loss of YABBY function. The $Y A B B Y$ genes are regulated by players involved in adaxial/abaxial polarity specification viz. KANADI, HDZIPIII, AS [103,111,120] (Figure 3D). This was also verified by a recent study that identified KAN1 and ARF4 as positively regulated targets of FIL/YAB3 and vice versa [121] (Figure 3D).

Analyses on genes of the WUSCHEL (WUS)-RELATED $H O M E O B O X(W O X)$ family shed further light on the mechanism of lateral organ outgrowth through evidences that emerged from preliminary studies on narrow sheath (ns1) and ns2, two duplicated genes of the WOX family found in maize. The $n s$ mutant plants displayed extremely narrow leaves, but their length were not compromised as compared to wild type plants [52], suggesting an unconnected relationship between the medial/lateral and proximodistal axes. In situ hybridization revealed that the expression of the $n s 1$ and $n s 2$ genes in maize occurs in the lateral domains of shoot meristem and the margins of young lateral organ primordia [53], thereby hinting at their involvement in promoting lamina outgrowth. In Arabidopsis, localization of the lateral-axis dependent gene PRESSED FLOWER (PRS) specified similar pattern of expression as the $n s$ genes, spatiotemporally expressed in the margins of sepals, petal, stamens, and developing leaves [54]. Furthermore, gain-of-function mutants of the PRS gene resulted in epidermal outgrowths on sepal margins while loss-of-function mutant displayed defects in the marginal regions of sepal, indicating that PRS is essential for the proliferation of marginal cells [54]. Isolation and characterization of MAEWEST (MAW) gene, which encodes a member of WOX family, in Petunia $\times$ hybrida highlighted its role in lamina outgrowth specification [55]. Double mutants of MAW and CHORIPETALA SUZANNE (CHSU) resulted in severely defective lamina outgrowth displaying mostly abaxialized cell types at the leaf margins. WOX1, an Arabidopsis $M A W$ ortholog, mutants showed no apparent abnormal phenotype, but 
when crossed with prs mutants, resulting F2 populations displayed narrow leaf lamina and thickened leaf margins similar in phenotype to maw mutants, indicative of their redundant roles in promoting lateral lamina outgrowth [55,112]. WOX1 is expressed in the leaf meristem (plate meristem), overlapping with $P R S[54,122]$. Based on the expression levels of PRS and WOX1 genes in $Y A B B Y$ gene family mutants (fil yab3 and fil yab3 yab5) and kan1 kan2 mutants backgrounds, WOX1 was shown to be upregulated by $Y A B B Y$ genes while $P R S$ remained unaffected and KAN represses both genes in the abaxial domain of leaf primordia [123] (Figure 3D).

During leaf morphogenesis, free auxin is systematically reallocated from the tip of the leaf (site of initial synthesis) to the expanding leaf blade margins, finally ending in the midvein of the lamina [124]. This pattern of free auxin synthesis facilitates leaf blade outgrowth. Several lines of evidence support this notion, for example, broad exogenous application of IAA across one side of the developing leaf primordium of Solanum lycopersicum resulted in ectopic lamina outgrowth with maintained compoundness and asymmetry [125]. Similarly, at sites where ectopic auxin accumulation appeared - indicated through PIN1 expressions - as in the hypocotyls of kan1 kan2 kan4 triple mutants, ectopic leaf-like organs developed [126]. Furthermore, formation of ectopic bulges at the sides of developing leaf primordium of yabby quadruple mutants corresponds to sites where secondary PIN1 convergence points occurred [51]. More convincing results emerged from studies of YUCCA (YUC) gene family encoding flavin monooxygenase-like enzymes involved in local auxin biosynthesis. Mutations in four (yuc1246) of the 11 Arabidopsis YUC genes caused severe defects on plant stature and leaf development (narrow leaves), besides other developmental processes such as vascular and floral patterning [56,57]. When mutated YUC124 genes were constructed in as2 rev and kan1 kan2 backgrounds (polarity defective mutants), severely defective phenotypes with extremely narrow leaves was observed [127]. Interestingly, the pentuple mutants lack the finger-shaped protrusions evident in as 2 rev and kan1 kan 2 mutants formed as a result of ectopic juxtaposition of the leaf adaxial and abaxial domains [103,128]. Wang et al. [127] showed that these protrusions represent hydathodes-like structures, thereby suggesting that $y u c$ genes, in response to adaxial-abaxial juxtaposition, promote leaf margin development and blade outgrowth via local auxin accumulation [112].

\section{Leaf expansion and maturation}

Once the establishment of leaf polarity along the threedimensional axes is achieved, leaf begins to expand until it acquires its final size and shape. Prior to cell expansion, cells divide and grow, that is, proliferate. Proliferation occurs early during leaf development and spreads throughout the leaf primordia [129,130]. At this stage, cells undergo successive mitotic cell cycle exemplified by expression pattern of CYC1 [129] and the presence of cells with variable C-DNA content [131]. Genes that are exclusively expressed at this phase includes members of A- and B-type cyclin family, known to control the activity of cyclin-dependent kinases (CDKs) and other downstream transcriptional complexes [132]. Once cell proliferation ceases, cells immediately switch to expansion mode via endoreduplication. It may be mentioned here that certain species such as Aquilegia vulgaris, Lactuca serriola, and Oryza sativa show little or no endoreduplication event, despite their small genome size [131]. Initiation of endoreduplication is indicated by the emergence of cells with $8 \mathrm{C}$ and 16C DNA content [132]. At this stage, cell cycling pattern partition the leaf into three regions: the proliferative cells containing basal region, the distal region that comprises expanding cells and the boundary that separates the basal/distal region termed the cell cycle arrest front. The progression of the cell cycle arrest front during the transition phase is an abrupt process [133,134], and the timing of its appearance is an important factor for determining the final size of the lateral organ [130]. When expansion terminates, cells become mature. Maturation is indicated by the increasing levels of KRP proteins that inhibit cell cycle progression, and stable DNA distribution and cell number [132].

Previous genetic analyses have identified key regulatory components of cell proliferation. Interaction between the transcription coactivator ANGUSTIFOLIA3 (AN3) and transcription factor GROWTH-REGULATING FACTOR5 (GRF5) has been shown to regulate leaf size and shape; mutation in these genes resulted in plants with narrow-leaf and decreased cell number [58,59]. More recent evidence has emerged that linked cell proliferation and adaxial/abaxial patterning as well. Mutational studies of the AN3 and AS2 genes showed that an 3 enhances leaf polarity defects in as 1 and as 2 mutants [135]. But the narrow-leaf phenotype of an3 is a consequence of a growth defect rather than a polarity defect, which implies that AN3 act at a specific developmental phase to regulate cell proliferation and polarity specification [135]. Besides GRFs, CYTOKININ RESPONSE FACTOR2 (CRF2), CONSTANS-LIKE5 (COL5), HECATE1 (HEC1), and ARABIDOPSIS RESPONSE REGULATOR4 (ARR4) were identified as prominent transcription factors that are regulated by AN3 through binding to SWITCH/SUCROSE NONFERMENTING (SWI/SNF) chromatin remodeling complexes [136]. Other regulators of cell proliferation include CINCINNATA (CIN), a member of the TCP gene family which contains the bHLH motif that permits DNA binding and proteinprotein interactions [137]. CIN mutants of $A$. majus displayed enhanced cell proliferation at the leaf margins 
producing large crinkled leaves [60]. Overexpression of TCP4, a CIN-like TCP gene, disrupted normal leaf morphogenesis resulting in small cup-shaped leaves due to early onset of maturation and decreased cell proliferation [138].

In an attempt to understand how leaf size and shape varies among plants, Kuchen et al. [139] devised an experimentally validated model to help define the evolution and development of diverse organ shapes. The model correctly matches the observed growth dynamics and shape changes of leaf 1 in Arabidopsis. To account for leaf shape other than leaf 1 , the authors varied the effects of two factors, among the many specified: PGRAD, defined to express as a linear gradient along the proximodistal axis, and LAM, defined to express everywhere. Varying the effects of PGRAD at the distal end and the strength of promotion by LAM resulted in the generation of diverse morphospace resembling some of the botanically described leaf shapes (for example, obcordata, ovate, and elliptic). The underlying genes that may explain these patterns include $L E A F Y$ PETIOLE and YABBY genes as candidates of LAM factor while CUC genes may underlie PGRAD factor [139]. This model, which also accurately predicts the growth patterns of Antirrhinum leaves [139], provides a framework for the experimental testing of the control of organ shape in diverse plant species.

\section{Leaf margin alterations: mir164A, CUC2, PIN1, and DPA4 are key players}

Growth and development in all three axes transforms the small bulging leaf initials on the periphery of the SAM into a flattened structure of varying sizes and shape. If leaf development were to stop here, we might expect leaf margins of the same type. But the characteristic nature of the leaf margin and the underlying mechanisms that exist confers additional complexity resulting in leaves of diverse marginal leaf shapes. Leaf margins are of different types: entire, serrate or lobed; it was until 2006 that the molecular mechanisms of leaf margin serration in Arabidopsis could be elucidated. In Arabidopsis, serration in leaves become more pronounced as the plant develop, with early rosette leaves showing less serration as compared to the ones that developed later ([61] and references therein), and this has been shown to be controlled by mir164A, CUC2, PIN1, and DPA4 [61,63,140,141] (Figure 4). Knock-out mutations in mir164a resulted in plants with deeper serrations as compared to wild type plants, caused as a result of a disruption in the miR164dependent regulation of $C U C 2$, a member of the $N A C$ gene family [61]. In mir164a cuc2 double mutant plants, leaf serration is lost suggesting that $C U C 2$ play a key role in the development of serrated leaf margins in Arabidopsis, and the degree of serration depends on the balance between the co-expressed MIR164A and CUC2

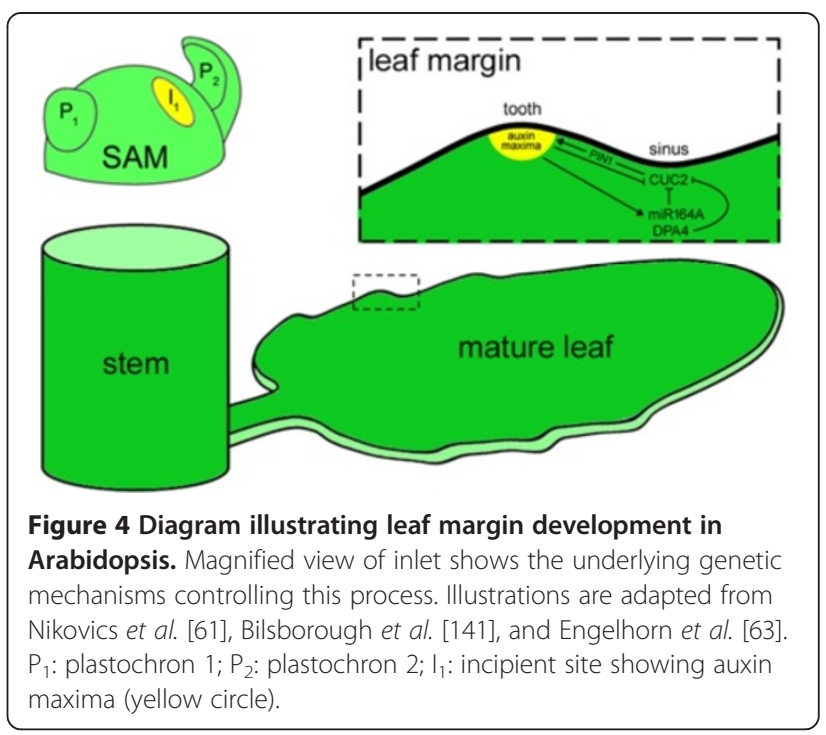

genes [61]. Contrary to the findings of Nikovics et al. [140], Kawamura et al. [140] showed that CUC2 promotes teeth outgrowth rather than suppressing the sinus growth.

Serration initiates at sites where auxin maxima occurs, as evidenced by expression of the auxin response sensor DR5::GFP, with concurrent repression of CUC2 [141]. Eliminating this interspersed distribution through exogenous application of auxin and continuous CUC2 expression at the marginal domain resulted in leaves with smooth margins. Furthermore, based on PIN1 localization in cuc2 mutants, Bilsborough et al. [141] showed that CUC2 expression is required to induce PIN1 convergence points in the leaf margins. These results show the existence of a PIN1-mediated feedback regulatory loop between CUC2 and auxin [141] (Figure 4). Loss of PIN1 function resulted in plants with smooth margins [62]. In another recent study, it was shown that DEVELOPMENT-RELATED PcG TARGET IN THE APEX (DPA) genes contributed to the late-stage development of leaf margin serration in Arabidopsis [63]. T-DNA inserted DPA4 lines displayed enhanced leaf margin serrations while 35S::DPA4 overexpressor lines lacked serrated leaf margins. In situ hybridization and qRT-PCR analysis indicated that CUC2 expression in 35S::DPA4 lines were strongly downregulated hinting at an additive role by DPA4 in repressing CUC2 expression and thereby confirming the crucial role of $C U C 2$ in leaf margin serrations formation in Arabidopsis [63] (Figure 4). Besides CUC2, CUC3 was also shown to promote Arabidopsis leaf serration, but acts later in development mainly for teeth growth maintenance [142]. Earlier, ectopic KNAT1 expression transformed simple Arabidopsis leaves into lobed leaves, and lobing was shown to initiate at sites where leaf margin serration develop [143]. Double transgenic Arabidopsis lines ectopically overexpressing 
KNAT1 and PALMATE-LIKE PENTAFOLIATA1 (PALM1), a $\mathrm{Cys}(2) \mathrm{His}(2)$ zinc finger transcription factor involved in compound leaf development in $M$. truncata, displayed normal leaves suggesting a PALM1-mediated repression of KNAT1 via regulation of downstream targets [144]. Leaf margin serration is apparent in compound-leafed species as well, such as M. truncata; here, serration is confined to the distal part of leaflets. As was reported in Arabidopsis [141], leaf distal margin development in $M$. truncatula requires the auxin efflux protein MtPIN10 [145]. Plants with mutated PIN10 gene exhibited complete loss of serration [145]. In a recent study, insertion mutation in the MtPHAN gene resulted in plants with deeper serrations as compared to wild type, suggesting that MtPHAN also play key roles in leaf margin development [146]. When both mtphan mtpin10 genes were mutated, the compound leaves displayed smooth margins [146], confirming the crucial role of PIN10 in distal leaf margin development of $M$. truncata. Genetic evidences from simple and compound leaved-species identify transmembrane PIN proteins as crucial players of leaf margin development.

\section{Environmental basis of leaf shape: biotic and abiotic components}

Our understanding on the genetic basis of leaf shape diversity has come from the enormous amount of research conducted on model plant species. In the process, evidences that point to the role of environmental cues on leaf shape determination emerged. For example, the phan mutants of Antirrhinum majus analyzed for dorsiventrality specification displayed varying phenotypes when grown at different temperatures [37]. At $17^{\circ} \mathrm{C}$, leaves are needlelike, reverting to normal types at higher temperature $\left(25^{\circ} \mathrm{C}\right)$, suggesting that PHAN expression respond differently and reveal the sensitivity of other gene components towards temperature changes [37]. This observation suggests that external factors play a role in shaping lateral organs. An overview on some of the environmental factors controlling leaf shape development is presented below.

\section{Role of temperature and light in leaf shape diversity}

Because of their fluctuating tendency, temperature and light regimes could adversely affect leaf growth processes and leaf shape [147]. Royer et al. [148] studied the effect of temperature gradient on leaf shape plasticity in Acer rubrum grown at two gardens with contrasting climates (Rhode Island and Florida, USA). Plants at Rhode Island garden, with mean annual temperature (MAT) of $9.8^{\circ} \mathrm{C}$, displayed highly dissected leaves with more number of teeth as compared to plants grown at Florida garden $\left(\mathrm{MAT}=20.0^{\circ} \mathrm{C}\right)$. This observation was corroborated by another study that spans 92 globally distributed and climatically diverse sites, and reported that plants found in colder climates develop larger, higher number of teeth and highly dissected leaves [149]. These results showed the apparent impact of environmental change on leaf shape variations.

But among all the causative environmental factors, which includes elevated $\mathrm{CO}_{2}$ [150] and gravity [5], light forms an important physical component that has tremendous impact on leaf shape [5,67]. Differences in light intensity resulted in plants with varying leaf forms: low intensity induces petiole elongation with reduced blade expansion whereas high intensity promoted blade expansion but inhibits the elongation of the leaf petiole [5]. More convincing results appeared from a study that showed how light affect leaf initiation and positioning [151]. In dark conditions, tomato seedlings ceased to initiate proper leaf development, but reassumed growth when transferred into light conditions [151], a response comparable to pea [152]. Moreover, the dark-grown seedlings displayed slender leaves as compared to light-grown seedlings. Based on the results that emerge through the use of norflurazon, a photosynthesis inhibitor, cessation of leaf initiation in tomato seedlings is independent of photosynthesis. Yoshida et al. [151] extended their study on tomato aurea mutants that lack proper phytochrome photoreceptor and found retarded leaf formation and irregular phyllotaxy in the mutants. These results suggest that light acts as a morphogenic signal that requires signaling molecule (auxin and cytokinin) to transduce its effect during leaf development.

In naturally limiting light conditions such as the understorey tropical rainforests, fascinating leaf variation exists. Plants of the genus Monstera develop holes in adult leaves, referred as leaf fenestration (Figure 1B). The display of leaf fenestration in adult leaves is intriguing and often rare, which lack convincing evolutionary explanation. In an attempt to reveal the basis of this morphological peculiarity, Muir [153] designed a model to test the hypothesis that leaf fenestration might offer adaptive significance for survival in the dark understorey tropical rainforests. Muir [153] used the model to compare between fenestrated (top) and entire (bottom) juvenile leaves where leaf area and mean daily leaf photosynthesis are same in both leaf shapes. Although the fenestrated leaf utilized less sunlight, intercepted as sunflecks (brief, intermittent, and unpredictable periods of direct light), as compared to entire leaves, the average carbon gain worked out is same. However, variance in canopy growth rate is lower in the fenestrated leaf. The model demonstrated that fenestration can reduce the variance in plant growth thereby increasing plant fitness, and this was shown to depend on the stochastic sources of light (sunfleck) for carbon gain [153]. It can be assumed that the tropical rainforest habitat imposed a selective pressure that drives the development of leaf fenestration. 


\section{Leaf shape variations as a response to herbivory}

Selection as a means that coerced the evolution of leaf size and shape has unexpected participation from the animal kingdom, particularly vertebrates and insects, through herbivory [6]. It was proposed that some of the variations seen in plants, for example, highly divided and dissected leaves, heteroblasty and interspecific differences in leaf form, may have evolved as a response to herbivory, to reduce the feeding efficiency or recognition by herbivores [6]. The theory was tested on the highly variable rosette leaves of Capsella bursa-pastoris for feeding preferences by adult flea beetles, Spodoptera caterpillars, and adult vine weevils [154]. Field and laboratory data for flea beetles, showing preferences for deeply lobed leaves, disprove the theory while Spodoptera caterpillars displayed no preference at all. The adult vine weevils, however, preferred undivided over divided leaves [154]. A similar experiment was conducted on Ipomoea hederacea, a plant with two genotypes showing either heart-shaped leaves (genotype 1) or both heart-shaped and three-lobed leaves (genotype 2), to study the effect of leaf shape on insect consumption and performance [155]. Interestingly, the heart-shaped genotypes suffered less damage from foraging by Spodoptera exigua (beet armyworms) as compared to lobed-shaped genotypes, but showed no significant effect between juvenile and adult heart-shaped leaves [155]. The above results suggest that herbivory as a means towards leaf shape determination lacked convincing and corroborative results, and this may be attributed to several additional factors that could influence the experimental outcome.

\section{Conclusions}

We conclude and recapitulate that leaf development and the diverse forms it attained is governed by complex genetic interactions, changes in gene expression patterns, participation of microRNAs, and active hormonal regulations, some of which are reprocessed during development or the specification of leaf types. Moreover, the effects of environmental factors in shaping lateral organs are also evident and probably act at a later stage of development for final adjustment. This evidence has expanded our knowledge on the mechanism of leaf development and shape determination; however, our understanding is limited to a few model plant species. In spite of tremendous progress in the field, gaps still exist. The findings that auxin does not promote leaf initiation in S. kraussiana nor does it affect leaf development in young pin 1 mutants of Arabidopsis indicate the existence of an auxin-independent mechanism. In a remarkable finding and one that downplayed the role of auxin in apical dominance, Mason et al. [156] identified sugar as the crucial regulator of axillary bud outgrowth in plants. As a complement to this finding and an indication that sugar may play a role in leaf development, transcription factors that regulate genes involved in sugar signaling were highly expressed in the basal zone of maize leaf, a region where cell division and cell-fate specification occur [157]. Future research in these directions should hold promise in enhancing our knowledge of the initial events of leaf development. Following the recent discovery of APUM23 as a new regulator of leaf polarity specification, questions have arisen concerning their direct targets (among the known leaf polarity genes). But some of the old questions have remained unresolved, for example, what are the markers that specify proximodistal patterning or what is the nature of the SAM-derived signal required for normal adaxial/abaxial patterning? These and many more have eluded clarification. In addition, major breakthroughs in this field have come from research on plants with megaphyllous leaves. While certain studies have indicated conservation among genes involved in the initiation of megaphylls and microphylls (for example, KNOX, ARP) [20], some have suggested distinct functions (for example, role of class III HD-ZIPs in adaxial/abaxial polarity) [68]. To have a better understanding on the concept of leaf development across land plants, more research into microphyll development is indeed required.

Finally, taking into consideration the enormous amount of leaf shape diversity that plants exhibit, a shift into nonmodel plant species showing morphological novelties may be envisaged. One such example is the carnivorous plant genus Nepenthes, a remarkable botanical entity that is of significant interest in the context of plant adaptation. Nepenthes, especially N. khasiana (Figure 1B), typically grow in nutrient-deficient soil (particularly nitrogen) and in order to survive have developed specialized organs called pitchers, modified through a process of epiascidiation that involves in-rolling of the adaxial leaf surface followed by marginal fusion $[158,159]$. These pitchers have the ability to attract and capture insects, digest them, and ultimately absorb the nutrients. We understand why Nepenthes develop pitchers, but how it does remains a mystery? But with the advent of new high-throughput sequencing technologies, this mystery may be unfolded. So what valuable insight could a study on leaf development in Nepenthes offer? First, it would significantly contribute towards understanding the evolution of plant development, especially those that are adaptive in nature. Second, it would provide additional insights into the evolutionary origins of leaflike structures, and third, help in understanding how evolution works so as to develop strategies that will enable engineering and improvement of crop plants. Furthermore, the notion that Nepenthes pitchers are more specialized in carnivory as compared to other carnivorous plants [160] further justify this proposal. The origin of the pitcher is analogous to that of the leaf (particularly the megaphylls); the latter evolved in correlation 
with a drop in atmospheric $\mathrm{CO}_{2}[14]$ and the former is presumably linked with soil $\mathrm{N}_{2}$ reduction, although the association has not been proved yet. This phenomenon of carnivory is considered an 'opportunity to uncover macroevolutionary patterns and processes that may be generalized to other structural phenomena in angiosperms' [159]. We now know that simple leaves are determinate appendages; whether pitchers represent determinate morphological structures as well or are modifications that occur at later stages of development is a notion to fathom on. It is a known fact that auxin plays an important role in leaf development; how it controls pitcher development is another interesting aspect that can be looked at? Based on the available information, it may be assumed that formation of the pitcher tube involves the recruitment of a genetic mechanism similar to the one that occur during petal fusion (sympetaly) in Petunia, a process known to involve $M A W$ and CHSU [55]. This assumption stems out from the observation that lateral leaf outgrowth is also severely affected in maw cshu mutants displaying extremely narrow leaves [55]. In line with these investigations, similar genetic analysis can be performed and tested, which requires the availability of the genome or transcriptome sequence of Nepenthes for gene mining. In recent years, reports on the genome sequences of some carnivorous plants have been made available $[161,162]$; these resources may offer additional insights on the evolution of morphological novelties.

\section{Abbreviations}

AN3: Angustifolia3; APUM23: Arabidopsis pumilio23; ARF: Auxin response factor; ARF3: Auxin response factor3; ARF4: Auxin response factor4; ARP: Asymmetric leaves1/roughsheath2/phantastica; ARR: Arabidopsis response regulator; AS1: Asymmetric leaves1; AS2: Asymmetric leaves2; BP: Brevipedicellus; CDKs: Cyclin-dependent kinases; CIN: Cincinnata; CK: Cytokinin; CLV: Clavata; CRC: Crabs claw; CSHU: Choripetala suzanne; CUC2: Cup shaped cotyledon2; CUC3: Cup shaped cotyledon3; CYC1: Cyclin1; DCL4: Dicer-like4; DPA4: Development-related PCG target in the apex4; ETT: Ettin; FlL: Filamentous flower; GA: Gibberellin; ga2ox1: GA2-oxidase1; ga2ox2: GA2-oxidase2; GA20ox: GA20-oxidase; GARP: Glutamic acid-rich protein; GRF5: Growth-regulating factor5; GRN: Gene regulatory network; HD-ZIPIII: Class III homeodomain-leucine zipper; HIRA: Histone regulator A; IAA: Indole-3-acetic acid; ig: Indeterminate gametophyte; INO: Inner no outer; IPT7: Isopentenyl transferase 7; KNOX1: Class-1 knotted-like homeobox; KN1: Knotted1; KNAT1: Knotted-like from arabidopsis thaliana1; KAN: Kanadi; KAN1: Kanadi1; KAN2: Kanadi2; KAN3: Kanadi 3; KRP: Kip related proteins; L1: Layer 1 of shoot apical meristem; LePHAN: Lycopersicum esculentum PHANTASTICA; Lgn-R: Liguleless narrow-reference; LOB: Lateral organ boundaries; MAT: Mean annual temperature; MAW: Maewest; mir164A: microRNA164A; miR165: microRNA165; miR166: microRNA166; NAC: NAM No apical meristem; ATAF: Arabidopsis transcription activation factor; CUC: Cup-shaped cotyledon; NPH3: Non-phototropic hypocotyl 3; ns1: Narrow sheath1; ns2: Narrow sheath2; OSHB: Oryza sativa homeobox; OSHB1: Oryza sativa homeobox1; OSHB3: Oryza sativa homeobox3; OSHB4: Oryza sativa homeobox4; PALM1: Palmate-like pentafoliata1; PHAN: Phantastica; PHB: Phabulosa; PHV: Phavoluta; PIN: Pin-formed; PIN1: Pin-formed1; PIN2: Pin-formed2; PIN3: Pin-formed3; PIN4: Pin-formed4; PIN7: Pin-formed7; PRC2: Polycomb repressive complex2; PRS: Pressed flower; PUF: Pumilio/fem-3 mRNA binding factor; RDR6: RNA-dependent RNA polymerase6; REV: Revoluta; RS2: Roughsheath2; SAM: Shoot apical meristem; siRNA: Small interfering RNA; STM: Shoot meristemless; TAA1: Tryptophan aminotransferase of arabidopsis 1; TAS3: Trans-acting small interfering RNA
}

precursor RNA; tasi-RNA: Trans-acting small interfering RNA; TCP: Teosinte-like1: cycloidea and proliferating cell factor1; WOX: Wuschel-related homeobox; WOX1: Wuschel-related homeobox 1; WUS: Wuschel; YAB: Yabby; YAB2: Yabby2; YAB3: Yabby3; YAB5: Yabby5; YUC: Yucca; YUC124: Yucca1/ yucca2/yucca4; YUC1246: Yucca1/yucca2/yucca4/yucca6; ZmPIN1: Zea mays pin-formed 1

\section{Competing interests}

The authors declare that they have no competing interests.

\section{Authors' contributions}

JD and AP conceptualized and designed the review. JD wrote the manuscript and prepared the figures. Both authors read and approved the final manuscript.

\section{Acknowledgement}

The authors acknowledge two anonymous reviewers for critical reading and suggestions to improve the manuscript. Financial assistance to JD from the Department of Science \& Technology, Government of India under the DST INSPIRE Faculty Scheme (IFA12-LSPA-07) is acknowledged. Authors are grateful to Mr. Christopher Muir, Indiana University; Dr. Hamidou Sakhanokho, USDA; Dr. Pedro Cardoso, University of Helsinki; and Mr. Thomas Tam of Prof. Liam Dolan Lab, University of Oxford for providing the photographs of Monstera deliciosa, Christia obcordata, Selaginella kraussiana, and Physcometrilla patens, respectively. Authors would like to thank Prof. SK Sopory, Vice-Chancellor, Jawaharlal Nehru University, New Delhi for the valuable comments made on the earlier version of the manuscript. Authors would also like to extend their gratitude towards the Department of Biotechnology, Government of India for their continuous financial support to the SPMB Laboratory.

Received: 18 September 2014 Accepted: 8 December 2014

Published: 22 December 2014

\section{References}

1. Nicotra AB, Leigh A, Boyce K, Jones CS, Niklas KJ, Royer DL, Tsukaya H: The evolution and functional significance of leaf shape in the angiosperms. Funct Plant Biol 2011, 38:535-552.

2. McDonald PG, Fonseca CR, Overton JM, Westoby M: Leaf-size divergence along rainfall and soil-nutrient gradients: is the method of size reduction common among clades? Funct Ecol 2003, 17:50-57.

3. Nicotra AB: Leaf size and shape. Prometheus Wiki 2011, [http:// prometheuswiki.publish.csiro.au/tiki-index.php?page=Leaf+size+and+shape]

4. Scoffoni C, Rawls M, McKown A, Cochard H, Sack L: Decline of leaf hydraulic conductance with dehydration: relationship to leaf size and venation architecture. Plant Physiol 2011, 156:832-843.

5. Tsukaya H: Leaf shape: genetic control and environmental factors. Int J Dev Biol 2005, 49:547-555.

6. Brown VK, Lawton JH: Herbivory and the evolution of leaf size and shape. Philos Trans R Soc Lond B 1991, 333:265-272.

7. Kaplan DR, Groff PA: Developmental themes in vascular plants: functional and evolutionary significance. In Experimental and Molecular Approaches to Plant Biosystematics. Edited by Hoch PC, Stephenson AJ. St. Louis, MO: Missouri Botanical Garden; 1995:111-145.

8. Gifford EM, Foster AS: Morphology and Evolution of Vascular Plants. 3rd edition. New York: WH Freeman; 1989.

9. Stewart WN, Rothwell GW: Paleobotany and the Evolution of Plants. 2nd edition. Cambridge: Cambridge University Press; 1993.

10. Kaplan DR: The science of plant morphology: definition, history and role in modern biology. Am J Bot 2001, 88:1711-1741.

11. Tomescu AMF: Megaphylls, microphylls and the evolution of leaf development. Trends Plant Sci 2009, 14:5-12.

12. Kenrick P, Crane PR: The origin and early evolution of plants on land. Nature 1997, 389:33-39.

13. Gensel PG, Andrews HN: Plant Life in the Devonian. New York: Praeger; 1984

14. Beerling DJ, Osborne CP, Chaloner WG: Evolution of leaf-form in land plants linked to atmospheric $\mathrm{CO}_{2}$ decline in the Late Palaeozoic era. Nature 2001, 410:352-354.

15. Bower FO: Primitive Land Plants also known as the Archegoniatae. London: Macmillan; 1935. 
16. Hao S, Beck CB, Deming W: Structure of the earliest leaves: adaptations to high concentrations of atmospheric $\mathrm{CO}_{2}$. Int J Plant Sci 2003, 164:71-75.

17. Zimmermann W: Main results of the "telome theory". Palaeobotanist 1952, $1: 456-470$.

18. Pryer KM, Schneider H, Smith AR, Cranfill R, Wolf PG, Hunt JS, Sipes SD: Horsetails and ferns are a monophyletic group and the closest living relatives to seed plants. Nature 2001, 409:618-622.

19. Goliber T, Kessler S, Chen JJ, Bharathan G, Sinha N: Genetic, molecular, and morphological analysis of compound leaf development. Curr Top Dev Biol 1999, 43:259-290.

20. Harrison CJ, Corley SB, Moylan EC, Alexander DL, Scotland RW, Langdale JA: Independent recruitment of a conserved developmental mechanism during leaf evolution. Nature 2005, 434:509-514

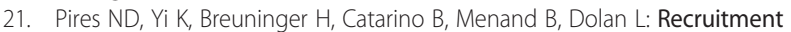
and remodeling of an ancient gene regulatory network during land plant evolution. Proc Natl Acad Sci U S A 2013, 110:9571-9576.

22. Blein T, Pulido A, Vialette-Guiraud A, Nikovics K, Morin H, Hay A, Johansen IE, Tsiantis M, Laufs P: A conserved molecular framework for compound leaf development. Science 2008, 322:1835-1839.

23. Okada K, Ueda J, Komaki MK, Bell CJ, Shimura Y: Requirement of the auxin polar transport system in early stages of Arabidopsis floral bud formation. Plant Cell 1991, 3:677-684.

24. Galweiler L, Guan C, Muller A, Wisman E, Mendgen K, Yephremov A, Palme K: Regulation of polar auxin transport by AtPIN1 in Arabidopsis vascular tissue. Science 1998, 282:2226-2230.

25. Reinhardt D, Pesce ER, Stieger P, Mandel T, Baltensperger K, Bennett M, Traas J, Friml J, Kuhlemeier C: Regulation of phyllotaxis by polar auxin transport. Nature 2003, 426:255-260.

26. Long JA, Moan El, Medford Jl, Barton MK: A member of the KNOTTED class of homeodomain proteins encoded by the STM gene of Arabidopsis. Nature 1996, 379:66-69.

27. Kerstetter RA, Laudencia-Chingcuanco D, Smith LG, Hake S: Loss-of-function mutations in the maize homeobox gene, knotted1, are defective in shoot meristem maintenance. Development 1997, 124:3045-3054

28. Laux T, Mayer KFX, Berger J, Jürgens G: The WUSCHEL gene is required for shoot and floral meristem integrity in Arabidopsis. Development 1996, 122:87-96.

29. Clark SE, Running MP, Meyerowitz EM: CLAVATA1, a regulator of meristem and flower development in Arabidopsis. Development 1993, 119:397-418.

30. Clark SE, Running MP, Meyerowitz EM: CLAVATA3 is a specific regulator of shoot and floral meristem development affecting the same processes as CLAVATA1. Development 1995, 121:2057-2067.

31. Byrne ME, Barley R, Curtis M, Arroyo JM, Dunham M, Hudson A, Martienssen RA: Asymmetric leaves 1 mediates leaf patterning and stem cell function in Arabidopsis. Nature 2000, 408:967-971.

32. Tsiantis M, Schneeberger R, Golz JF, Freeling M, Langdale JA: The maize rough sheath2 gene and leaf development programs in monocot and dicot plants. Science 1999, 284:154-156

33. Timmermans MC, Hudson A, Becraft PW, Nelson T: ROUGH SHEATH2: a Myb protein that represses knox homeobox genes in maize lateral organ primordia. Science 1999, 284:151-153.

34. Waites $R$, Selvadurai HR, Oliver IR, Hudson A: The PHANTASTICA gene encodes a MYB transcription factor involved in growth and dorsoventrality of lateral organs in Antirrhinum. Cell 1998, 93:779-789.

35. Ramirez J, Bolduc N, Lisch D, Hake S: Distal expression of knotted1 in maize leaves leads to reestablishment of proximal/distal patterning and leaf dissection. Plant Physiol 2009, 151:1878-1888.

36. Moon J, Candela H, Hake S: The Liguleless narrow mutation affects proximaldistal signalling and leaf growth. Development 2013, 140:405-412.

37. Waites R, Hudson A: phantastica: a gene required for dorsoventrality of leaves in Antirrhinum majus. Development 1995, 121:2143-2154.

38. $X u L, X u$ Y, Dong A, Sun Y, Pi L, Huang H: Novel as1 and as2 defects in leaf adaxial-abaxial polarity reveal the requirement for ASYMMETRIC LEAVES1 and 2 and ERECTA functions in specifying leaf adaxial identity. Development 2003, 130:4097-4107.

39. McConnell R, Emery JF, Eshed Y, Bao N, Bowman J, Barton MK: Role of PHABULOSA and PHAVOLUTA in determining radial patterning in shoots. Nature 2001, 411:709-713.

40. Emery JF, Floyd SK, Alvarez J, Eshed Y, Nawker NP, Izhaki A, Baum SF, Bowman JL: Radial patterning of Arabidopsis shoots by class III HD-ZIP and KANADI genes. Curr Biol 2003, 13:1768-1774.
41. Kerstetter RA, Bollman K, Taylor RA, Bomblies K, Poethig RS: KANADI regulates organ polarity in Arabidopsis. Nature 2001, 411:706-709.

42. Eshed Y, Baum SF, Perea JV, Bowman JL: Establishment of polarity in lateral organs of plants. Curr Biol 2001, 11:1251-1260.

43. Huang T, Kerstetter R, Irish VF: APUM23, a PUF family protein, functions in leaf development and organ polarity in Arabidodpsis. J Exp Bot 2014, 65:1181-1191

44. Pekker I, Alvarez JP, Eshed Y: Auxin response factors mediate Arabidopsis organ asymmetry via modulation of KANADI activity. Plant Cell 2005 17:2899-2910

45. Zhou G-K, Kubo M, Zhong R, Demura T, Ye Z-H: Overexpression of miR165 affects apical meristem formation, organ polarity establishment and vascular development in Arabidopsis. Plant Cell Physiol 2007, 48:391-404.

46. Kim J, Jung J-H, Reyes JL, Kim Y-S, Kim S-Y, Chung K-S, Kim JA, Lee M, Lee Y, Kim VN, Chua N-H, Park C-M: microRNA-directed cleavage of ATHB15 mRNA regulates vascular development in Arabidopsis inflorescence stems. Plant J 2005, 42:84-94.

47. Peragine A, Yoshikawa M, Wu G, Albrecht HL, Poethig RS: SGS3 and SGS2/ SDE1/RDR6 are required for juvenile development and the production of trans-acting siRNAs in Arabidopsis. Genes Dev 2004, 18:2368-2379.

48. Xie Z, Allen E, Wilken A, Carrington JC: DICER-LIKE 4 functions in trans-acting small interfering RNA biogenesis and vegetative phase change in Arabidopsis thaliana. Proc Natl Acad Sci U S A 2005, 102:12984-12989.

49. Fahlgren N, Montgomery TA, Howell MD, Allen E, Dvorak SK, Alexander AL, Carrington JC: Regulation of AUXIN RESPONSE FACTOR3 by TAS3 ta-siRNA affects developmental timing and patterning in Arabidopsis. Curr Biol 2006, 16:939-944

50. Kumaran MK, Bowman $J$, Sundaresan V: YABBY polarity genes mediate the repression of KNOX homeobox genes in Arabidopsis. Plant Cell 2002, $14: 2761-2770$

51. Sarojam R, Sappl PG, Goldshmidt A, Efroni I, Floyd SK, Eshed Y, Bowman JL Differentiating Arabidopsis shoots from leaves by combined YABBY activities. Plant Cell 2010, 22:2113-2130

52. Scanlon MJ, Schneeberger RG, Freeling M: The maize mutant narrow sheath fails to establish leaf margin identity in a meristematic domain. Development 1996, 122:1683-1691.

53. Nardmann J, Ji J, Werr W, Scanlon MJ: The maize duplicate genes narrow sheath1 and narrow sheath2 encode a conserved homeobox gene function in a lateral domain of shoot apical meristem. Development 2004, 131:2827-2839.

54. Matsumoto N, Okada K: A homeobox gene, PRESSED FLOWER, regulates lateral axis-dependent development of Arbidopsis flowers. Genes Dev 2001, 15:3355-3364.

55. Vandenbussche M, Horstman A, Zethof J, Koes R, Rijpkema AS, Gerats T: Differential recruitment of WOX transcription factors for lateral development and organ fusion in Petunia and Arabidopsis. Plant Cell 2009, 21:2269-2283.

56. Cheng $Y$, Dai $X$, Zhao $Y$ : Auxin biosynthesis by the YUCCA flavin monooxygenases controls the formation of floral organs and vascular tissues in Arabidopsis. Genes Dev 2006, 20:1790-1799.

57. Cheng $Y$, Dai $X$, Zhao $Y$ : Auxin synthesized by the YUCCA flavin monooxygenases is essential for embryogenesis and leaf formation in Arabidopsis. Plant Cell 2007, 19:2430-2439.

58. Kim JH, Kende $\mathrm{H}$ : A transcriptional coactivator, AtGIF1, is involved in regulating leaf growth and morphology in Arabidopsis. Proc Natl Acad SCi US A 2004, 101:13374-13379.

59. Horiguchi G, Kim G-T, Tsukaya H: The transcription factor AtGRF5 and the transcription coactivator AN3 regulate cell proliferation in leaf primordia of Arabidopsis thaliana. Plant J 2005, 43:68-78.

60. Nath U, Crawford BCW, Carpenter R, Coen E: Genetic control of surface curvature. Science 2003, 299:1404-1407

61. Nikovics $K$, Blein T, Peaucelle A, Ishida T, Morin H, Aida M, Laufs P: The balance between the MIR164A and CUC2 genes controls leaf margin serration in Arabidopsis. Plant Cell 2006, 18:2929-2945.

62. Hay A, Barkoulas M, Tsiantis M: ASYMMETRIC LEAVES1 and auxin activities converge to repress BREVIPEDICELLUS expression and promote leaf development in Arabidopsis. Development 2006, 133:3955-3961.

63. Engelhorn J, Reimer JJ, Leuz I, Göbel U, Huettel B, Farrona S, Turck F: DEVELOPMENT-RELATED PCG TARGET IN THE APEX 4 controls leaf margin architecture in Arabidopsis thaliana. Development 2012, 139:2566-2575. 
64. Poethig RS, Sussex IM: The cellular parameters of leaf development in tobacco; A clonal analysis. Planta 1985, 165:170-184.

65. Dolan L, Poethig RS: Clonal analysis of leaf development in cotton. Am J Bot 1998, 85:315-321.

66. Moon J, Hake S: How a leaf gets its shape. Curr Opin Plant Biol 2011, 14:24-30.

67. Fambrini M, Pugliesi C: Usual and unusual development of the dicot leaf: involvement of transcription factors and hormones. Plant Cell Rep 2013, 32:899-922.

68. Floyd SK, Bowman JL: Distinct developmental mechanisms reflect the independent origins of leaves in vascular plants. Curr Biol 2006, 16:1911-1917.

69. Harrison CJ, Rezvani M, Langdale JA: Growth from two transient apical initials in the meristem of Selaginella kraussiana. Development 2007, 134:881-889.

70. Jackson D, Veit B, Hake S: Expression of maize KNOTTED1 related homeobox genes in the shoot apical meristem predicts patterns of morphogenesis in the vegetative shoot. Development 1994, 120:405-413.

71. Smith LG, Jackson D, Hake S: Expression of knotted1 marks shoot meristem formation during maize embryogenesis. Dev Genet 1995, 16:344-348.

72. Vernoux T, Kronenberger J, Grandjean O, Laufs P, Traas J: PIN-FORMED 1 regulates cell fate at the periphery of the shoot apical meristem. Development 2000, 127:5157-5165.

73. Reinhardt D, Mandel T, Kuhlemeier C: Auxin regulates the initiation and radial position of plant lateral organs. Plant Cell 2000, 12:507-518.

74. Benkova E, Michniewicz M, Sauer M, Teichmann T, Seifertova D, Jurgens G, Friml J: Local, efflux-dependent auxin gradients as a common module for plant organ formation. Cell 2003, 115:591-602.

75. Heisler MG, Ohno C, Das P, Sieber P, Reddy GV, Long JA, Meyerowitz EM: Patterns of auxin transport and gene expression during primordium development revealed by live imaging of the Arabidopsis inflorescence meristem. Curr Biol 2005, 15:1899-1911.

76. Scarpella E, Marcos D, Friml J, Berleth T: Control of leaf vascular patterning by polar auxin transport. Genes Dev 2006, 20:1015-1027.

77. Bayer EM, Smith RS, Mandel T, Nakayama N, Sauer M, Prusinkiewicz P, Kuhlemeier C: Integration of transport-based models for phyllotaxis and midvein formation. Genes Dev 2009, 23:373-384.

78. Forestan C, Meda S, Varotto S: ZmPIN1-mediated auxin transport is related to cellular differentiation during maize embryogenesis and endosperm development. Plant Physio/ 2010, 152:1373-1390.

79. Barkoulas M, Hay A, Kougioumoutzi E, Tsiantis M: A developmental framework for dissected leaf formation in the Arabidopsis relative Cardamine hirsuta. Nat Genet 2008, 40:1136-1141.

80. Hamant $O$, Heisler MG, Jönsson H, Krupinski P, Uyttewaal M, Bokov $P$, Corson F, Sahlin P, Boudaoud A, Meyerowitz EM, Couder Y, Traas J: Developmental patterning by mechanical signals in Arabidopsis. Science 2008, 322:1650-1655.

81. Guo X, Lu W, Ma Y, Qin Q, Hou S: The BIG gene is required for auxinmediated organ growth in Arabidopsis. Planta 2013, 237:1135-1147.

82. Guenot B, Bayer E, Kierzkowski D, Smith RS, Mandel T, Žádníková P, Benková E, Kuhlemeier C: PIN1-independent leaf initiation in Arabidopsis. Plant Physiol 2012, 159:1501-1510.

83. Sanders HL, Langdale JA: Conserved transport mechanisms but distinct auxin responses govern shoot patterning in Selaginella kraussiana. New Phytol 2013, 198:419-428.

84. Nishii K, Möller M, Kidner C, Spada A, Mantegazza R, Wang CN, Nagata T: A complex case of simple leaves: indeterminate leaves co-express ARP and KNOX1 genes. Dev Genes Evol 2010, 220:25-40.

85. Koltai H, Bird DM: Epistatic repression of PHANTASTICA and class 1 KNOTTED genes is uncoupled in tomato. Plant J 2000, 22:455-459.

86. Veit B: Hormone mediated regulation of the shoot apical meristem. Plant Mol Biol 2009, 69:397-408.

87. Jasinski S, Piazza P, Craft J, Hay A, Woolley L, Rieu I, Phillips A, Hedden P, Tsiantis M: KNOX action in Arabidopsis is mediated by coordinate regulation of cytokinin and gibberellin activities. Curr Biol 2005, 15:1560-1565.

88. Yanai O, Shani E, Dolezal K, Tarkowski P, Sablowski R, Sandberg G, Samach A, Ori N: Arabidopsis KNOX1 proteins activate cytokinin biosynthesis. Curr Biol 2005, 15:1566-1571.

89. Hay A, Kaur H, Phillips A, Hedden P, Hake S, Tsiantis M: The gibberellin pathway mediates KNOTTED1-type homeobox function in plants with different body plans. Curr Biol 2002, 12:1557-1565.
90. Bolduc N, Hake S: The maize transcription factor KNOTTED1 directly regulates the gibberellin catabolism gene ga2ox1. Plant Cell 2009, 21:1647-1658.

91. Leibfried A, To JPC, Busch W, Stehling S, Kehle A, Demar M, Kieber JJ, Lohmann JU: WUSCHEL controls meristem function by direct regulation of cytokinin-inducible response regulators. Nature 2005, 438:1172-1175.

92. Scanlon MJ: The polar auxin transport inhibitor N-1-naphthylphthalamic acid disrupts leaf initiation, KNOX protein regulation, and formation of leaf margins in maize. Plant Physiol 2003, 133:597-605.

93. Zhao Z, Andersen SU, Ljung K, Dolezal K, Miotk A, Schultheiss SJ, Lohmann $J U:$ Hormonal control of the shoot stem cell niche. Nature 2010, 465:1089-1092.

94. Su Y-H, Liu Y-B, Zhang X-S: Auxin-cytokinin interaction regulates meristem development. Mol Plant 2011, 4:616-625.

95. Phelps-Durr TL, Thomas J, Vahab P, Timmermans MCP: Maize rough sheath2 and its Arabidopsis orthologue ASYMMETRIC LEAVES1 interact with HIRA, a predicted histone chaperone, to maintain Knox gene silencing and determinacy during organogenesis. Plant Cell 2005, 17:2886-2898.

96. Harrison J, Möller M, Langdale J, Cronk Q, Hudson A: Role of KNOX genes in the evolution of morphological novelty in Streptocarpus. Plant Cell 2005, 17:430-443.

97. Hay A, Tsiantis M: The genetic basis for differences in leaf form between Arabidopsis thaliana and its wild relative Cardamine hirsuta. Nat Genet 2006, 38:942-947.

98. Shani E, Burko Y, Ben-Yaakov L, Berger Y, Amsellem Z, Goldshmidt A, Sharon $E$, Ori N: Stage-specific regulation of Solanum lycopersicum leaf maturation by class 1 KNOTTED1-LIKE HOMEOBOX proteins. Plant Cell 2009, 21:3078-3092.

99. Lodha M, Marco CF, Timmermans MCP: The ASYMMETRIC LEAVES complex maintains repression of KNOX homeobox genes via direct recruitment of Polycomb-repressive complex2. Genes Dev 2013, 27:596-601.

100. Iwakawa H, Ueno Y, Semiarti E, Onouchi H, Kojima S, Tsukaya H, Hasebe M, Soma T, Ikezaki M, Machida C, Machida Y: The ASYMMETRIC LEAVES2 gene of Arabidopsis thaliana, required for formation of a symmetric flat leaf lamina, encodes a member of a novel family of proteins characterized by cysteine repeats and a leucine zipper. Plant Cell Physiol 2002, 43:467-478.

101. Hake S, Smith HMS, Holtan H, Magnani E, Mele G, Ramirez J: The role of KNOX genes in plant development. Annu Rev Cell Dev Biol 2004, 20:125-151.

102. Martinez CC, Sinha NR: Genetic control of leaf shape. eLS 2013. doi:10.1002/9780470015902.a0020101.pub2.

103. Eshed Y, Izhaki A, Baum SF, Floyd SK, Bowman JL: Asymmetric leaf development and blade expansion in Arabidopsis are mediated by KANADI and YABBY activities. Development 2004, 131:2997-3006.

104. Sussex IM: Experiments on the cause of dorsiventrality in leaves. Nature 1951, 167:651-652.

105. Sussex IM: Experiments on the cause of dorsiventrality in leaves. Nature 1954, 174:351-352.

106. Reinhardt D, Frenz M, Mandel T, Kuhlemeier C: Microsurgical and laser ablation analysis of leaf positioning and dorsoventral patterning in tomato. Development 2005, 132:15-26.

107. Kim M, McCormick S, Timmermans M, Sinha N: The expression domain of PHANTASTICA determines leaflet placement in compound leaves. Nature 2003, 424:438-443.

108. Evans MMS: The indeterminate gametophyte1 gene of maize encodes a LOB domain protein required for embryo Sac and leaf development. Plant Cell 2007, 19:46-62.

109. Ostuga D, DeGuzman B, Prigge MJ, Drews JN, Clark SE: REVOLUTA regulates meristem initiation at lateral positions. Plant J 2001, 25:223-236.

110. Itoh J-I, Hibara K-I, Sato Y, Nagato Y: Developmental role and auxin responsiveness of class III homeodomain leucine zipper gene family members in rice. Plant Physiol 2008, 147:1960-1975.

111. Juarez MT, Twigg RW, Timmermans MC: Specification of adaxial cell fate during maize leaf development. Development 2004, 131:4533-4544.

112. Yamaguchi T, Nukazuka A, Tsukaya H: Leaf adaxial-abaxial polarity specification and lamina outgrowth: evolution and development. Plant Cell Physiol 2012, 53:1180-1194.

113. Huang T, Harrar V, Lin C, Reinhart B, Newell NR, Talavera-Rauh F, Hokin SA, Barton MK, Kerstetter RA: Arabidopsis KANADI1 acts as a transcriptional 
repressor by interacting with a specific cis-element and regulates auxin biosynthesis, transport, and signaling in opposition to HD-ZIPIII factors. Plant Cell 2014, 26:246-262.

114. Kelley DR, Arreola A, Gallagher TL, Gasser CS: ETTIN (ARF3) physically interacts with KANADI proteins to form a functional complex essential for integument development and polarity determination in Arabidopsis. Development 2012, 139:1105-1109.

115. Allen E, Xie Z, Gustafson AM, Carrington JC: MicroRNA-directed phasing during trans-acting siRNA biogenesis in plants. Cell 2005, 121:207-221.

116. Hagemann W, Gleissberg S: Organogenetic capacity of leaves: the significance of marginal blastozones in angiosperms. Plant Syst Evol 1996, 199:121-152

117. Floyd SK, Bowman JL: Gene expression patterns in seed plant shoot meristems and leaves: homoplasy or homology? J Plant Res 2010, 123:43-55.

118. Siegfried KR, Eshed Y, Baum SF, Ostuga D, Drews GN, Bowman JL: Members of the $Y A B B Y$ gene family specify abaxial cell fate in Arabidopsis. Development 1999, 126:4117-4128.

119. Bowman JL: The YABBY gene family and abaxial cell fate. Curr Opin Plant Biol 2000, 3:17-22

120. Li H, Xu L, Wang H, Yuan Z, Cao X, Yang Z, Zhang D, Xu Y, Huang H: The putative RNA-dependent RNA polymerase RDR6 acts synergistically with ASYMMETRIC LEAVES1 and 2 to repress BREVIPEDICELLUS and microRNA165/166 in Arabidopsis leaf development. Plant Cell 2005, $17: 2157-2171$

121. Bonaccorso O, Lee JE, Puah L, Scutt CP, Golz JF: FILAMENTOUS FLOWER controls lateral organ development by acting as both an activator and a repressor. BMC Plant Biol 2012, 12:176.

122. Nardmann J, Werr W: Symplesiomorphies in the WUSCHEL clade suggest that the last common ancestor of seed plants contained at least four independent stem cell niches. New Phytol 2013, 199:1081-1092.

123. Nakata M, Matsumoto N, Tsugeki R, Rikirsch E, Laux T, Okada K: Roles of the middle domain-specific WUSCHEL-RELATED HOMEOBOX genes in early development of leaves in Arabidopsis. Plant Cell 2012, 24:519-535.

124. Aloni R, Schwalm K, Langhans M, Ullrich Cl: Gradual shifts in sites of free-auxin production during leaf-primordium development and their role in vascular differentiation and leaf morphogenesis in Arabidopsis. Planta 2003, 216:841-853.

125. Koenig D, Bayer E, Kang J, Kuhlemeier C, Sinha N: Auxin patterns Solanum lycopersicum leaf morphogenesis. Development 2009, 136:2997-3006.

126. Izhaki A, Bowman JL: KANADI and class III HD-Zip gene families regulate embryo patterning and modulate auxin flow during embryogenesis in Arabidopsis. Plant Cell 2007, 19:495-508.

127. Wang W, Xu B, Wang H, Li J, Hung H, Xu L: YUCCA genes are expressed in response to leaf adaxial-abaxial juxtaposition and are required for leaf margin development. Plant Physiol 2001, 157:1805-1819.

128. Fu Y, Xu L, Xu B, Yang L, Ling Q, Wang H, Huang H: Genetic interactions between leaf polarity-controlling genes and ASYMMETRIC LEAVES1 and 2 in Arabidopsis leaf patterning. Plant Cell Physiol 2007, 48:724-735.

129. Donnelly PM, Bonetta D, Tsukaya H, Denglera RE, Denglera NG: Cell cycling and cell enlargement in developing leaves of Arabidopsis. Dev Biol 1999, 215:407-419.

130. Rodriguez RE, Debernardi JM, Palatnik JF: Morphogenesis of simple leaves: regulation of leaf size and shape. WIREs Dev Biol 2014, 3:41-57.

131. Barow M, Meister $A$ : Endopolyploidy in seed plants is differently correlated to systematics, organ, life strategy and genome size. Plant Cell Environ 2003, 26:571-584.

132. Beemster GTS, Veylder LD, Vercruysse S, West G, Rombaut D, Hummelen PV, Galichet A, Gruissem W, Inzé D, Vuylsteke M: Genome-wide analysis of gene expression profiles associated with cell cycle transitions in growing organs of Arabidopsis. Plant Physiol 2005, 138:734-743.

133. Kazama T, Ichihashi Y, Murata S, Tsukaya H: The mechanism of cell cycle arrest front progression explained by a KLUH/CYP78A5-dependent mobile growth factor in developing leaves of Arabidopsis thaliana. Plant Cell Physiol 2010, 51:1046-1054.

134. Andriankaja M, Dhondt S, De Bodt S, Vanhaeren H, Coppens F, De Milde L, Mühlenbock P, Skirycz A, Gonzalez N, Beemster GTS, Inzé D: Exit from proliferation during leaf development in Arabidopsis thaliana: a not-so-gradual process. Dev Cell 2012, 22:64-78.

135. Horiguchi G, Nakayama H, Ishikawa N, Kubo M, Demura T, Fukuda H, Tsukaya H: ANGUSTIFOLIA3 plays roles in adaxial/abaxial patterning and growth in leaf morphogenesis. Plant Cell Physiol 2011, 52:112-124.
136. Vercruyssen L, Verkest A, Gonzalez N, Heyndrickx KS, Eeckhout D, Han S-K, Jégu T, Archacki R, Leene JV, Andriankaja M, Bodt SD, Abeel T, Coppensa F Dhondt S, Milde LD, Vermeersch M, Maleux K, Gevaert K, Jerzmanowski A, Benhamed M, Wagner D, Vandepoele K, Jaeger GD, Inzé D: ANGUSTIFOLIA3 binds to SWI/SNF chromatin remodeling complexes to regulate transcription during Arabidopsis leaf development. Plant Cell 2014, 26:210-229.

137. Cubas P, Lauter N, Doebley J, Coen E: The TCP domain: a motif found in proteins regulating plant growth and development. Plant J 1999, $18: 215-222$

138. Sarvepalli K, Nath U: Hyper-activation of the TCP4 transcription factor in Arabidopsis thaliana accelerates multiple aspects of plant maturation. Plant J 2011, 67:595-607.

139. Kuchen EE, Fox S, de Reuille PB, Kennaway R, Bensmihen S, Avondo J, Calder GM, Southam P, Robinson S, Bangham A, Coen E: Generation of leaf shape through early patterns of growth and tissue polarity. Science 2012, 335:1092-1096.

140. Kawamura E, Horiguchi G, Tsukaya H: Mechanisms of leaf tooth formation in Arabidopsis. Plant J 2010, 62:429-441

141. Bilsborough GD, Runions A, Barkoulas M, Jenkins HW, Hasson A, Galinha C Laufs P, Hay A, Prusinkiewicz P, Tsiantis M: Model for the regulation of Arabidopsis thaliana leaf margin development. Proc Natl Acad Sci U S A 2011, 108:3424-3429.

142. Hasson A, Plessis A, Blein T, Adroher B, Grigg S, Tsiantis M, Boudaoud A Damerval C, Laufs P: Evolution and diverse roles of the CUP-SHAPED COTYLEDON genes in Arabidopsis leaf development. Plant Cell 2011, 23:54-68.

143. Chuck G, Lincoln C, Hake S: KNAT1 induces lobed leaves with ectopic meristems when overexpressed in Arabidopsis. Plant Cell 1996, 8:1277-1289.

144. Chen J, Yu J, Ge L, Wang H, Berbel A, Liu Y, Chen Y, Li G, Tadege M, Wen J, Cosson V, Mysore KS, Ratet P, Madueño F, Bai G, Chen R: Control of dissected leaf morphology by a Cys(2)His(2) zinc finger transcription factor in the model legume Medicago truncatula. Proc Natl Acad Sci U S A 2010, 107:10754-10759.

145. Peng J, Chen R: Auxin efflux transporter MtPIN10 regulates compound leaf and flower development in Medicago truncata. Plant Signal Behav 2011, 6:1537-1544

146. Ge L, Peng J, Berbel A, Madueño F, Chen R: Regulation of compound leaf development by PHANTASTICA in Medicago truncata. Plant Physiol 2014 164:216-228.

147. Walter A, Schurr U: Dynamics of leaf and root growth: endogenous control versus environmental impact. Ann Bot 2005, 95:891-900

148. Royer DL, Meyerson LA, Robertson KM, Adams JM: Phenotypic plasticity of leaf shape along a temperature gradient in Acer rubrum. PLOS One 2009, 4:e7653.

149. Peppe DJ, Royer DL, Cariglino B, Olive SY, Newman S, Leight E, Enikolopov G, Fernandez-Burgos M, Herrera F, Adams JM, Correa E, Currano ED, Erickson JM, Hinojosa LF, Hoganson JW, Iglesias A, Jaramillo CA, Johnson KR, Jordan GJ, Kraft NJB, Lovelock EC, Lusk CH, Niinemets Ü, Peñuelas J, Rapson G, Wing SL, Wright IJ: Sensitivity of leaf size and shape to climate: global patterns and paleoclimatic applications. New Phytol 2011, 190:724-739.

150. Thomas SC, Bazzaz FA: Elevated $\mathrm{CO}_{2}$ and leaf shape: are dandelions getting toothier? Am J Bot 1996, 83:106-111.

151. Yoshida S, Mandel T, Kuhlemeier C: Stem cell activation by light guides plant organogenesis. Genes Dev 2011, 25:1439-1450.

152. Low VHK: Effects of light and darkness on the growth of peas. Aust J Biol Sci 1970, 24:187-195.

153. Muir CD: How did the Swiss cheese plant get its holes? Am Nat 2013, 181:273-281.

154. Rivero-Lynch AP, Brown VK, Lawton JH: The impact of leaf shape on the feeding preference of insect herbivores: experimental and field studies with Capsella and Phyllotreta. Philos Trans R Soc Lond B 1996, 351:1671-1677.

155. Campitelli BE, Simonsen AK, Wolf AR, Manson JS, Stinchcombe JR: Leaf shape variation and herbivore consumption and performance: a case study with Ipomoea hederacea and three generalists. Arthropod Plant Interact 2008, 2:9-19.

156. Mason MG, Ross JJ, Babst BA, Wienclaw BN, Beveridge CA: Sugar demand, not auxin, is the initial regulator of apical dominance. Proc Natl Acad Sci U S A 2014, 111:6092-6097.

157. Li P, Ponnala L, Gandotra N, Wang L, Si Y, Tausta SL, Kebrom TH, Provart N, Patel R, Myers CR, Reidel EJ, Turgeon R, Liu P, Sun Q, Nelson T, Brutnell TP: 
The developmental dynamics of the maize leaf transcriptome. Nat Genet 2010, 42:1060-1067.

158. Juniper BE, Robins RJ, Joel DM: The Carnivorous Plants. London: Academic; 1989.

159. Albert VA, Williams SE, Chase MW: Carnivorous plants: phylogeny and structural evolution. Science 1992, 257:1491-1495.

160. Pavlovič A, Masarovičová E, Hudák J: Carnivorous syndrome in Asian pitcher plants of the Genus Nepenthes. Ann Bot 2007, 100:527-536.

161. Leushkin EV, Sutormin RA, Nabieva ER, Penin AA, Kondrashov AS, Logacheva MD: The miniature genome of a carnivorous plant Genlisea aurea contains a low number of genes and short non-coding sequences. BMC Genomics 2013, 14:476.

162. Ibarra-Laclette E, Lyons E, Hernández-Guzmán G, Pérez-Torres CA, CarreteroPaulet L, Chang T-H, Lan T, Welch AJ, Juárez MJA, Simpson J, FernándezCortés A, Arteaga-Vázquez M, Góngora-Castillo E, Acevedo-Hernández G Schuster SC, Himmelbauer H, Minoche AE, Xu S, Lynch M, Oropeza-Aburto A, Cervantes-Pérez SA, Ortega-Estrada MJ, Cervantes-Luevano Jl, Michael TP, Mockler T, Bryant D, Herrera-Estrella A, Albert VA, Herrera-Estrella L: Architecture and evolution of a minute plant genome. Nature 2013, 498:94-98.

doi:10.1186/2041-9139-5-47

Cite this article as: Dkhar and Pareek: What determines a leaf's shape? EvoDevo 2014 5:47.

\section{Submit your next manuscript to BioMed Central and take full advantage of:}

- Convenient online submission

- Thorough peer review

- No space constraints or color figure charges

- Immediate publication on acceptance

- Inclusion in PubMed, CAS, Scopus and Google Scholar

- Research which is freely available for redistribution 